\title{
Long-Term Environmental Impacts of Pesticide and Herbicide Use in Panama Canal Zone
}

\author{
Kenneth R. Olson', Donna Tornoe ${ }^{2}$ \\ ${ }^{1}$ Professor Emeritus of Soil Science in the Department of Natural Resources and Environmental Sciences, College of Agricultural, \\ Consumer, and Environmental Sciences, University of Illinois, Urbana, USA \\ ${ }^{2}$ Director, Veterans of Panama Canal Zone, Military Veterans Advocacy, Slidell, USA \\ Email: krolson@illinois.edu
}

How to cite this paper: Olson, K.R. and Tornoe, D. (2021) Long-Term Environmental Impacts of Pesticide and Herbicide Use in Panama Canal Zone. Open Journal of Soil Science, 11, 403-434. https://doi.org/10.4236/ojss.2021.119021

Received: August 20, 2021

Accepted: September 4, 2021

Published: September 7, 2021

Copyright (c) 2021 by author(s) and Scientific Research Publishing Inc. This work is licensed under the Creative Commons Attribution International License (CC BY 4.0).

http://creativecommons.org/licenses/by/4.0/

\section{(cc) (i) Open Access}

\begin{abstract}
The opening of the Panama Canal in 1913 transformed ocean-shipping and the availability of internationally-traded goods, shortened travel time between the Pacific and Atlantic oceans, increased ship tonnage, and sparked the growth of port authorities on both the Atlantic and Pacific coasts of the Panama Canal. Historically, the United States was number one and China was number two in tons of cargo that pass through the canal annually in the high stakes game of import and export markets. Prior to the construction of the Panama Canal, the most efficient way to cross the 82-kilometer isthmus, between the Port of Panama City on the Pacific and the Port of Colon on the Atlantic, was by mule trails through tropical forests and river transportation. Since the construction of the Panama Canal through tropical forests in the 1910s, pesticides have been essential for managing mosquitoes as well as controlling wetland vegetation that blocked lakes, rivers and the canal. The primary objective of this research study is to document the long-term environmental impacts of pesticide and herbicide use in the Panama Canal Zone. Many of these chemicals, including 2,4,-D, 2,4,5-T and DDT, have a long half-life under water and some, like arsenic (As), have no half-life. Pesticides and chemicals flowed into Lake Gatun via surface runoff either in solution or attached to the sediment during the rainy season. The by-product 2,3,7,8-tetrachlorodibenzo- $p$-dioxin (TCDD) is an unanticipated contaminant created during the manufacture of the herbicide 2,4,5-T. TCDD can bio-accumulate in fish and birds and enter into the human food supply. The extent of the current chemical and pesticide contamination on former U.S. military base grounds and in Lake Gatun is unknown. Systematic soil sampling of current and former military bases, chemical disposal sites and Lake Gatun or the Panama Canal sediments is needed to determine if mitigation is necessary.
\end{abstract}




\section{Keywords}

Arsenic, Dams, DDT, Dioxin TCDD, 2,4-D, 2,4,5-T, Howard Air Force Base, Hyacinths, Lake Gatun, Locks, Mosquitoes, Pesticides, Termites

\section{Introduction}

Panama, a tropical nation is located on the Isthmus of Panama with 1,600 islands along its Atlantic and Pacific Ocean coasts (Figure 1). Panama is known for being the site of the Panama Canal which cuts through the middle of this Central American country. The country is known for its diversity of plant and animal life (Figure 2), natural beauty, music and culture. The country was the Native American home of the Guayni, Choco and Kuna indigenous people. In the 1530s Panama served as the home base for the Spanish conquest of the Inca Empire. In the $19^{\text {th }}$ century, Panama was the staging point for ocean-going migrants to the California and Alaska gold fields and the trans-shipment point for silver and gold destined for Spain [1].

Since 1914 the $82 \mathrm{~km}$ long Panama Canal (Figures 3-9) has served as the long-sought shortcut, saving thousands of kilometers, for shipping between the Pacific and Atlantic Oceans. Panama has become one of the most strategic transportation hubs of the world, assuring a major role in commerce and international affairs. The United States built the Panama Canal (Figure 10 and Figure 11) and maintained operational control (Figure 12) until December 31, 1999, when the U.S. returned control to Panama [2]. At that time the Panama government finally controlled all of its own territory. Panama City (Figures 13-18) is the capital and located east of the canal and on the Pacific Ocean coast. This cosmopolitan city of skyscrapers has become the financial and commercial center of Central America. The economic progress has been hampered by environmental problems and political turmoil. Panama and its capital enjoy a lively mix of cultural influences which include artwork, cuisine, literature and music [3].

The primary objective of this research study is to document the long-term, more than 100 years, environmental impacts of historic pesticide and herbicide use on the soils and water of the Panama Canal Zone and review the need for sampling of soils of former military bases and sediments in Lake Gatun and Panama Canal Zone for DDT, dioxin TCDD and As to determine if mitigation is necessary.

\section{Location of Site}

Panama is bounded on the south by the Pacific Ocean and to the north by Caribbean Sea, an extension of the Atlantic Ocean (Figure 1). Panama has an S-shape with a $1700 \mathrm{~km}$ long Pacific coast and a $1300 \mathrm{~km}$ Caribbean coast. A spine of mountain ranges extend almost the length of Panama. The central spine 


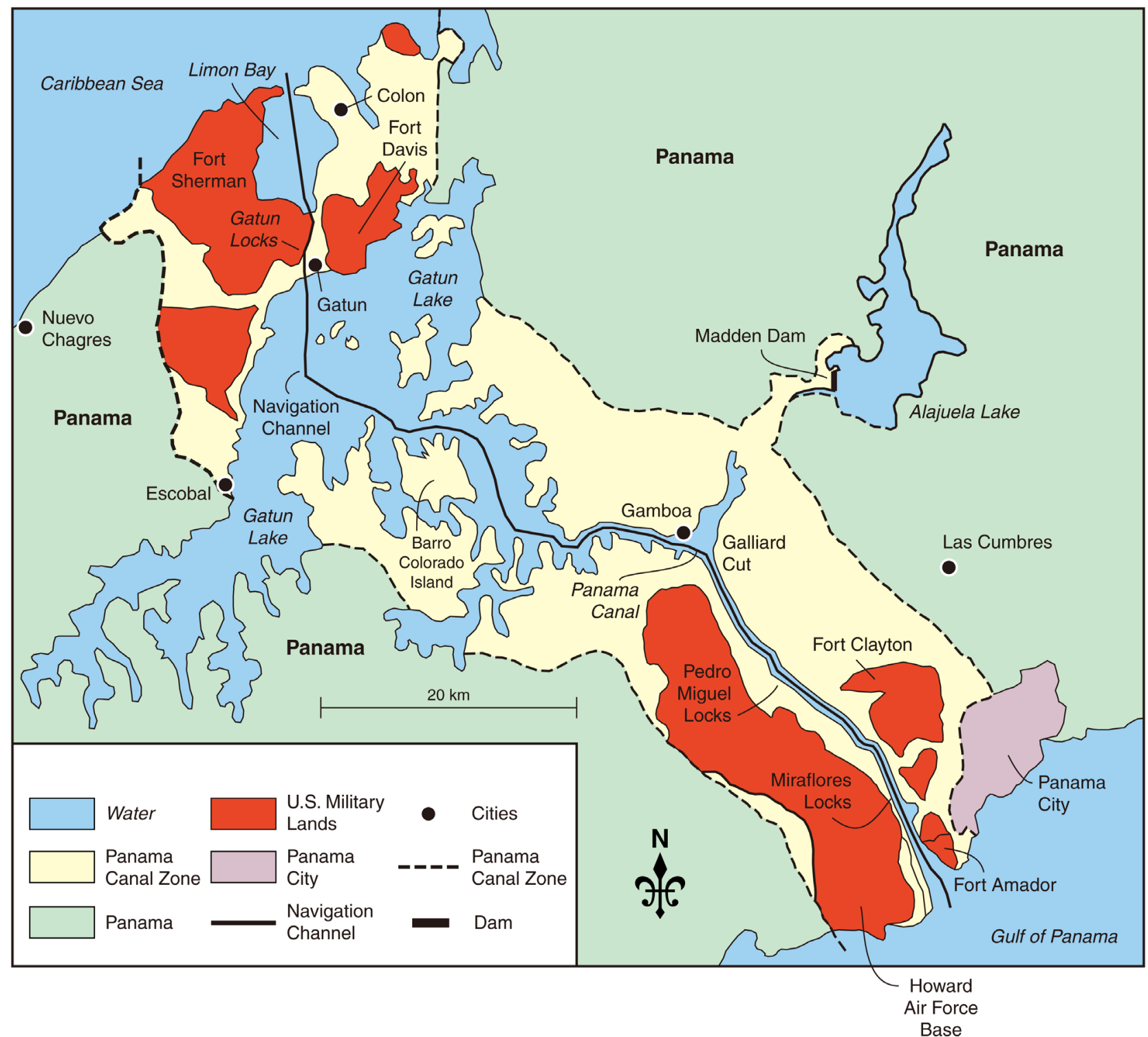

Figure 1. Panama Canal Zone map showing the Panama Canal, Lake Gatun, military bases and Panama City.

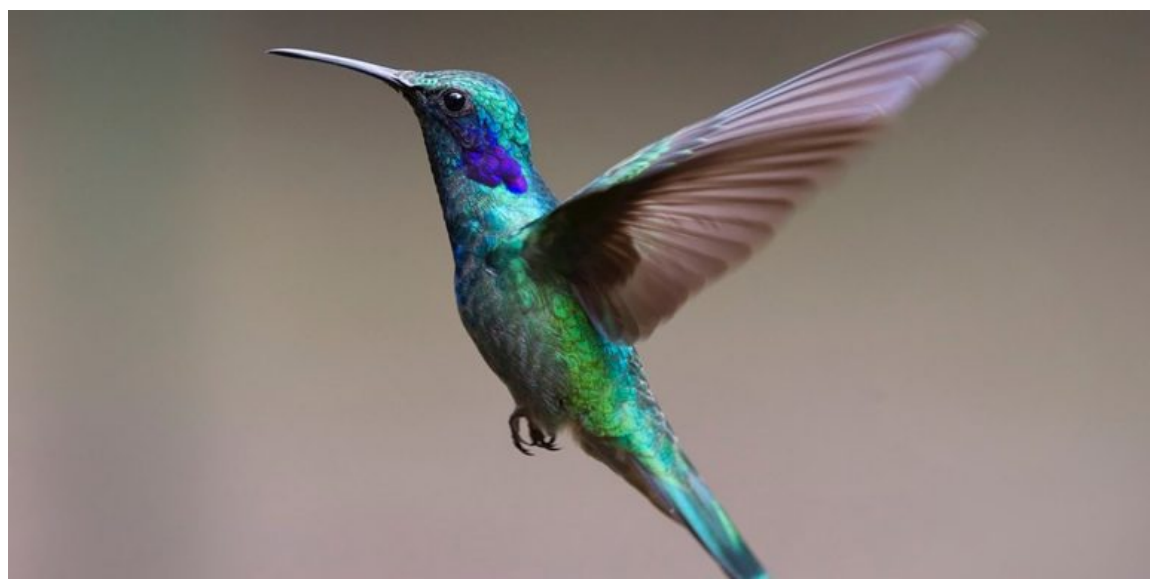

Figure 2. Humming bird in flight in the Panama Canal Zone. 


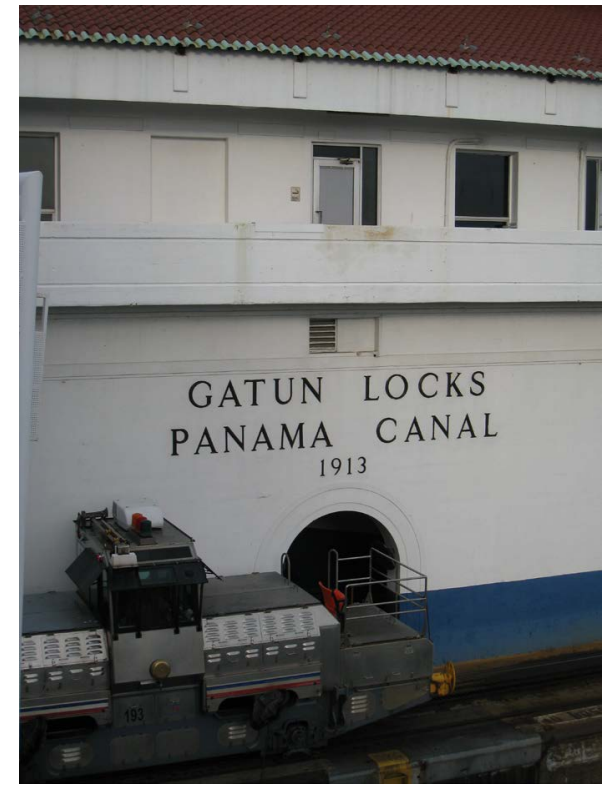

Figure 3. Gatun Locks sign dated 1913 at the Panama Canal.

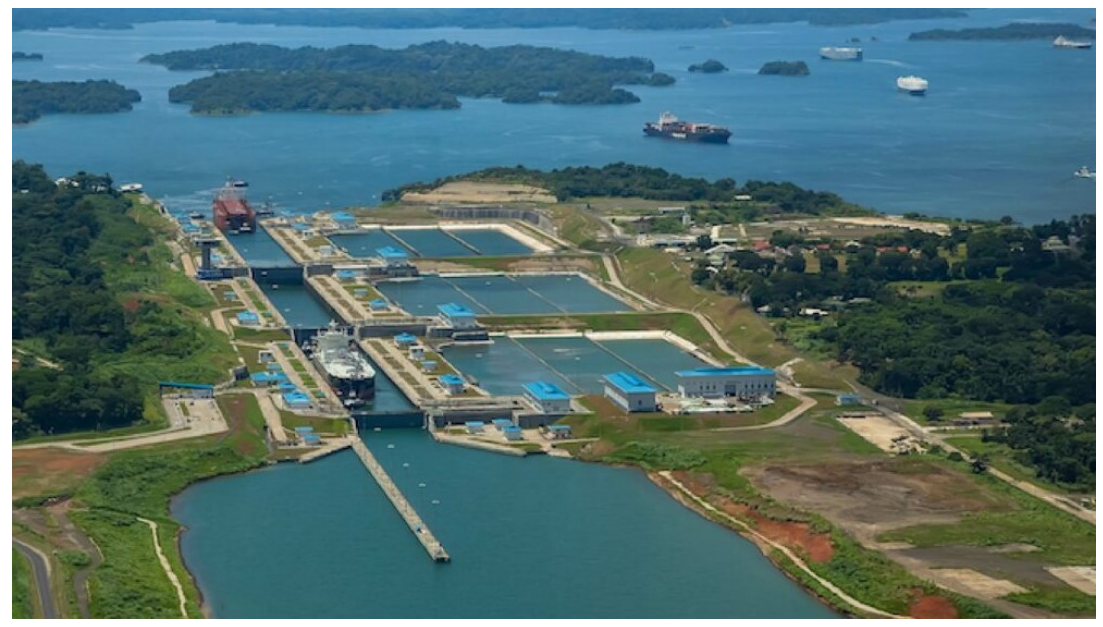

Figure 4. Locks at the southern (Pacific Ocean) entrance of Panama Canal Zone.

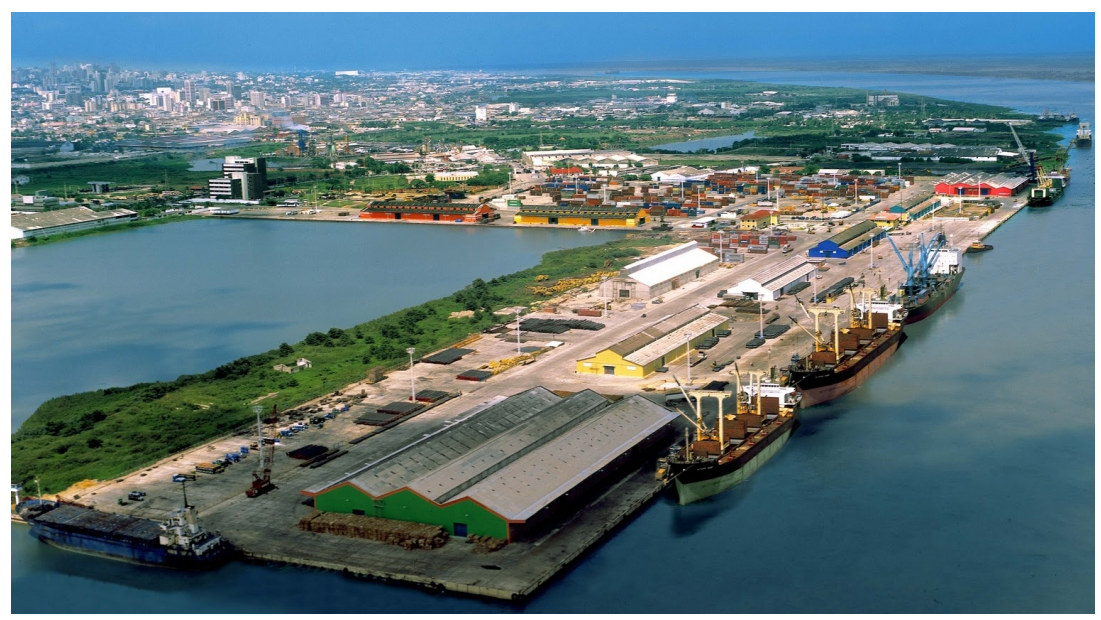

Figure 5. Four ships at a port near Panama City along the Panama Canal. 


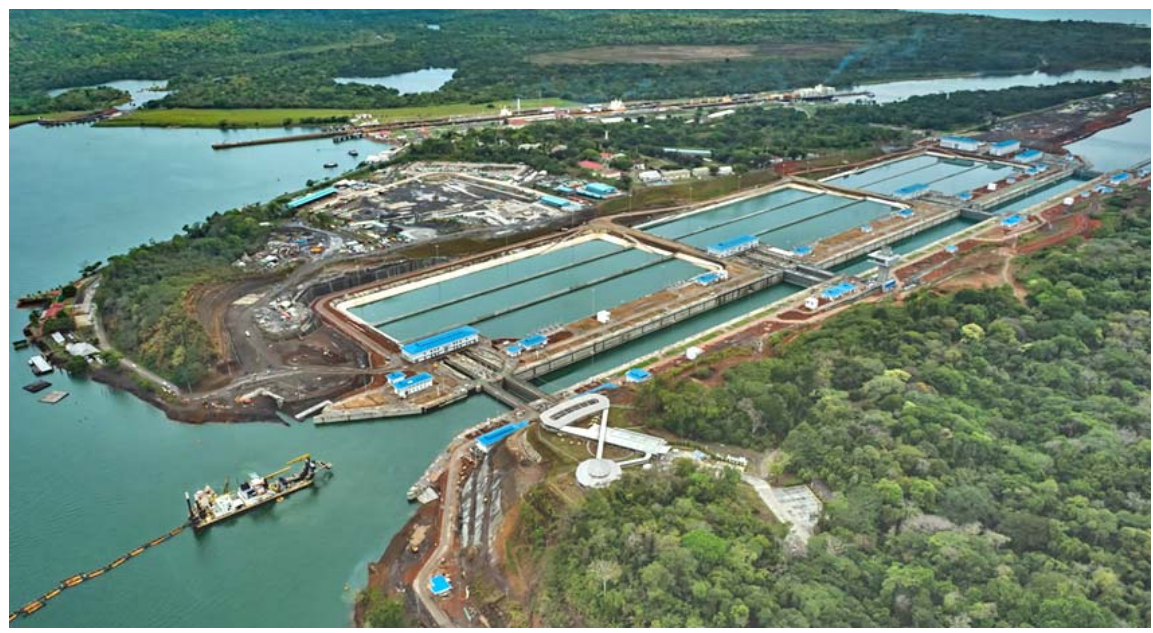

Figure 6. Locks on the southern entrance to the Panama Canal.

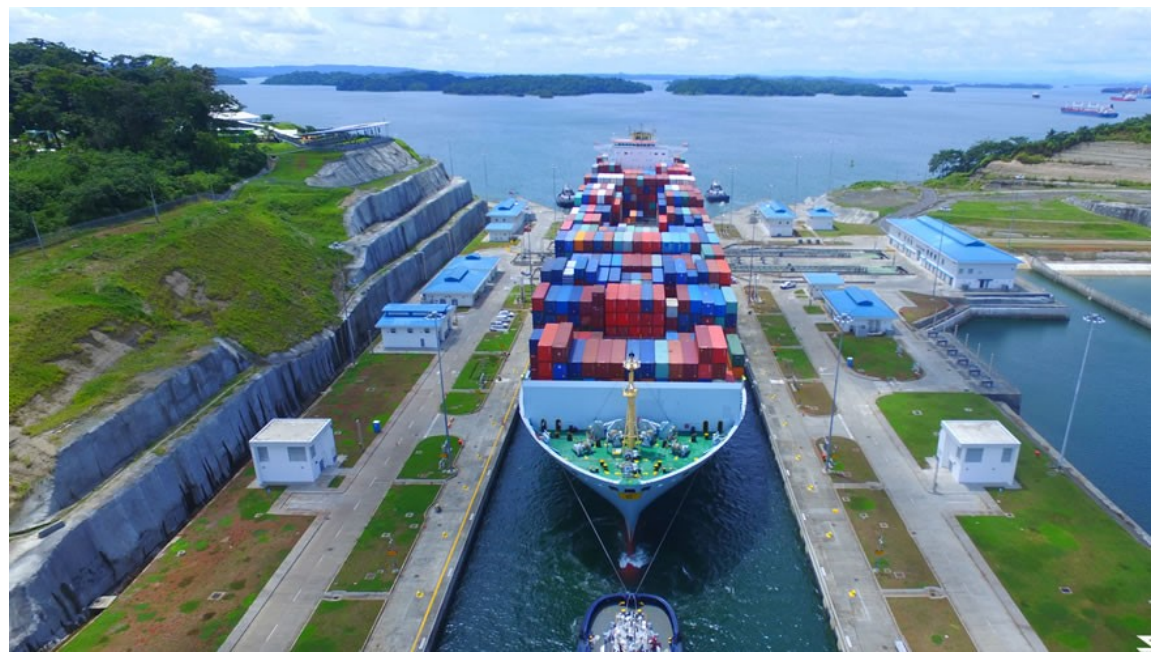

Figure 7. Loaded ship coming through a lock on the southern entrance to the Panama Canal.

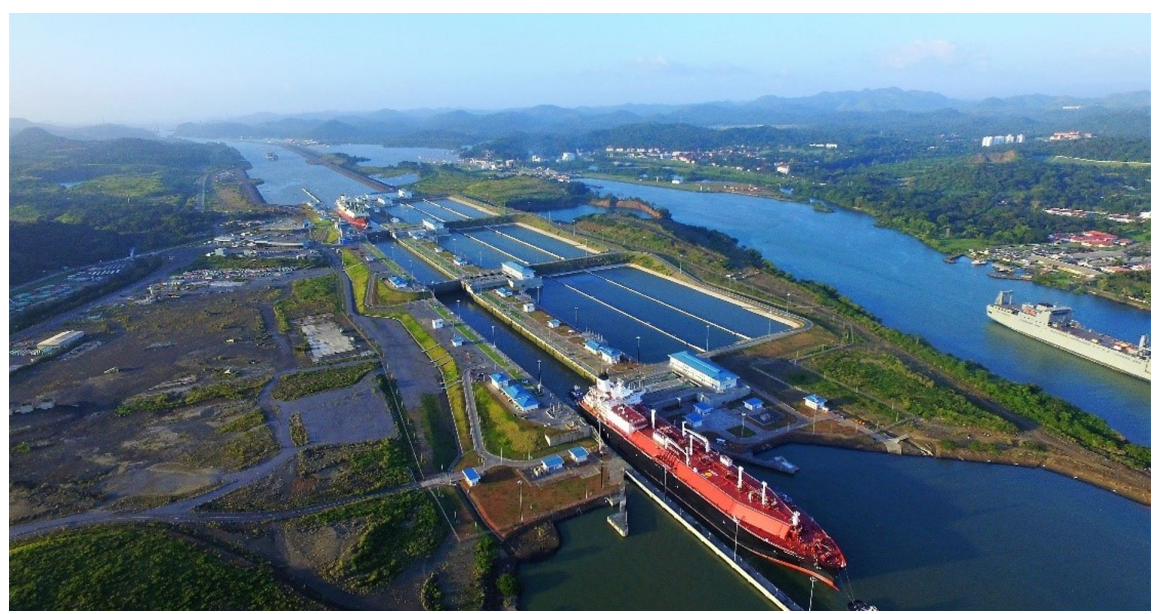

Figure 8. Ships going through a lock near the southern entrance of the Panama Canal. 


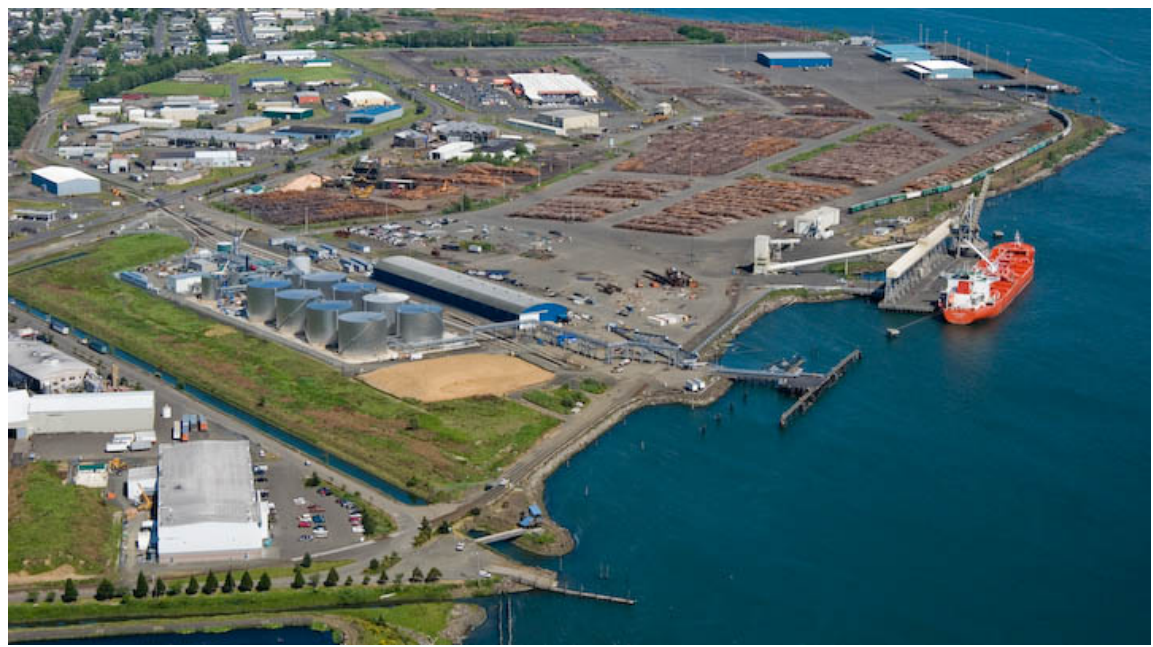

Figure 9. Ship docked at a Panama Canal harbor.

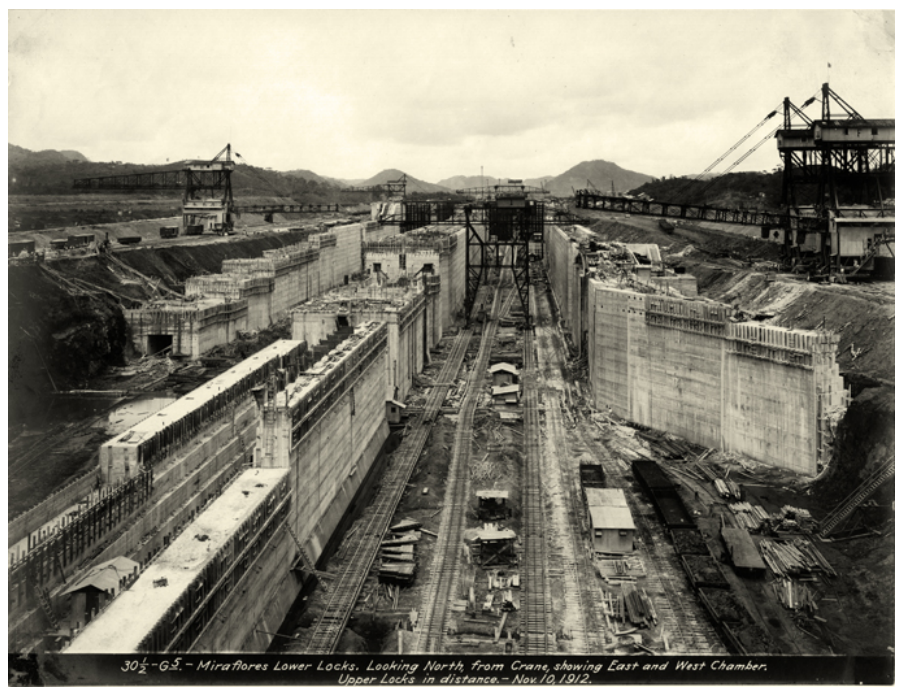

Figure 10. Construction in the early 1910s of a lock on the Panama Canal.

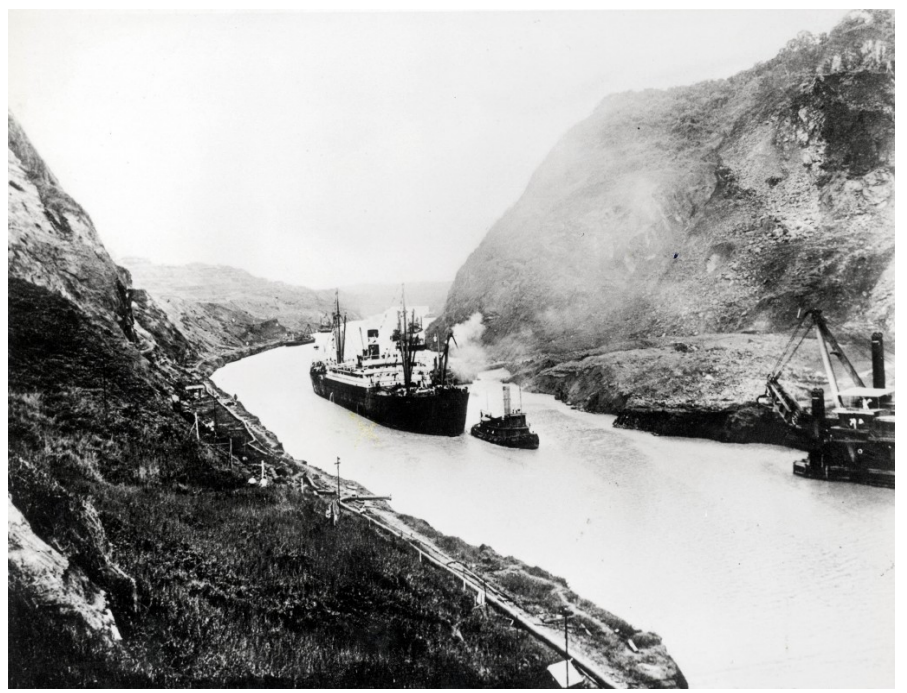

Figure 11. Tug boat pulling a ship through the Panama Canal in the 1910s. 


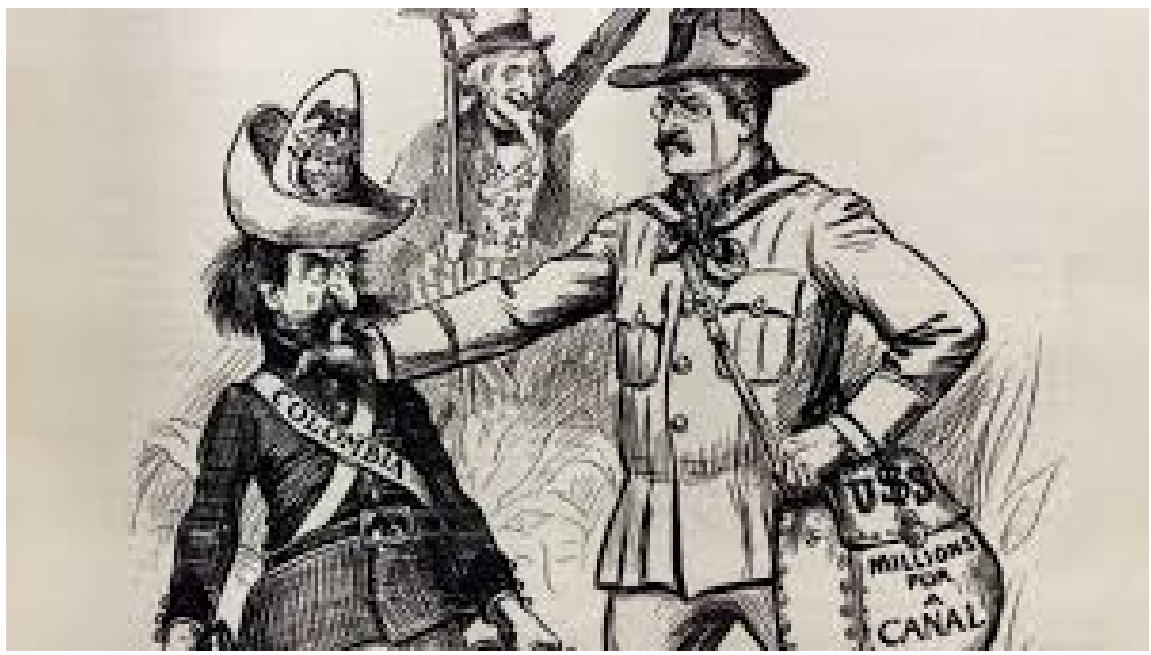

Figure 12. President Roosevelt enforcing his will on the leader of Colombia. The agreement was actually with Colombia and not Panama.

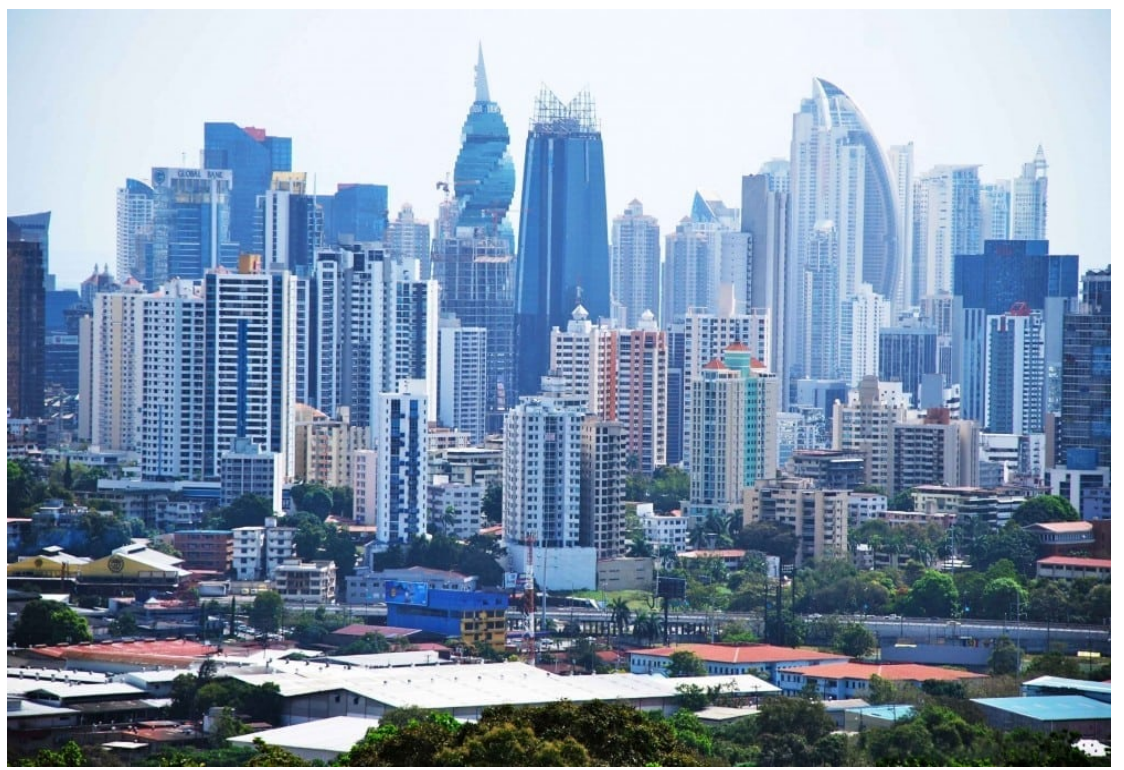

Figure 13. The modern Panama City skyline.

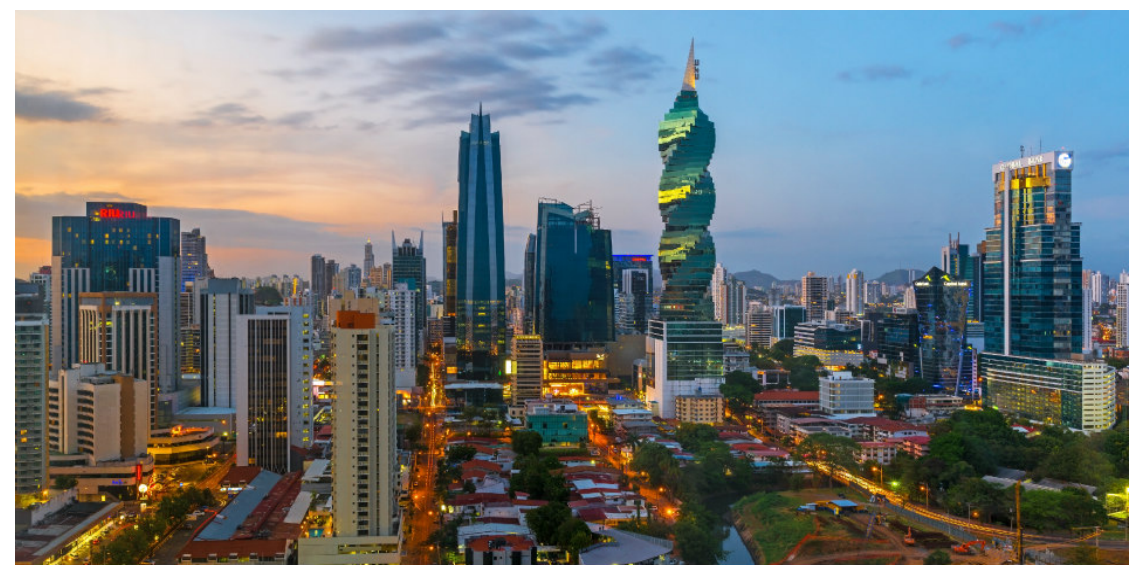

Figure 14. Panama City with modern twisted skyscraper. 


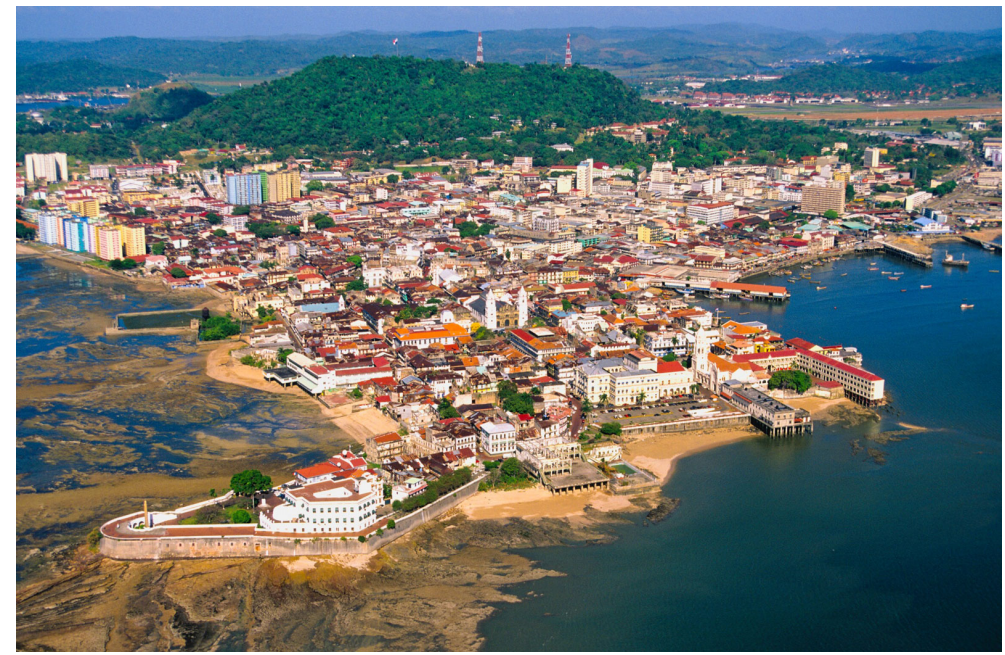

Figure 15. Panama City at the mouth of Panama Canal at Pacific Ocean.

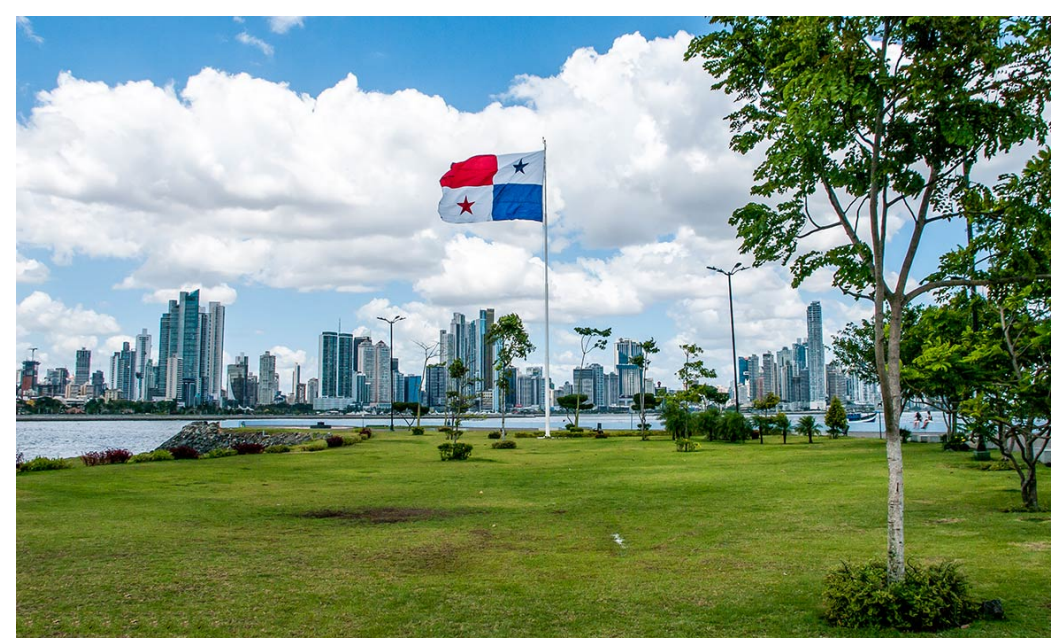

Figure 16. Panamanian flag and parkland across the canal from Panama City which is in background.

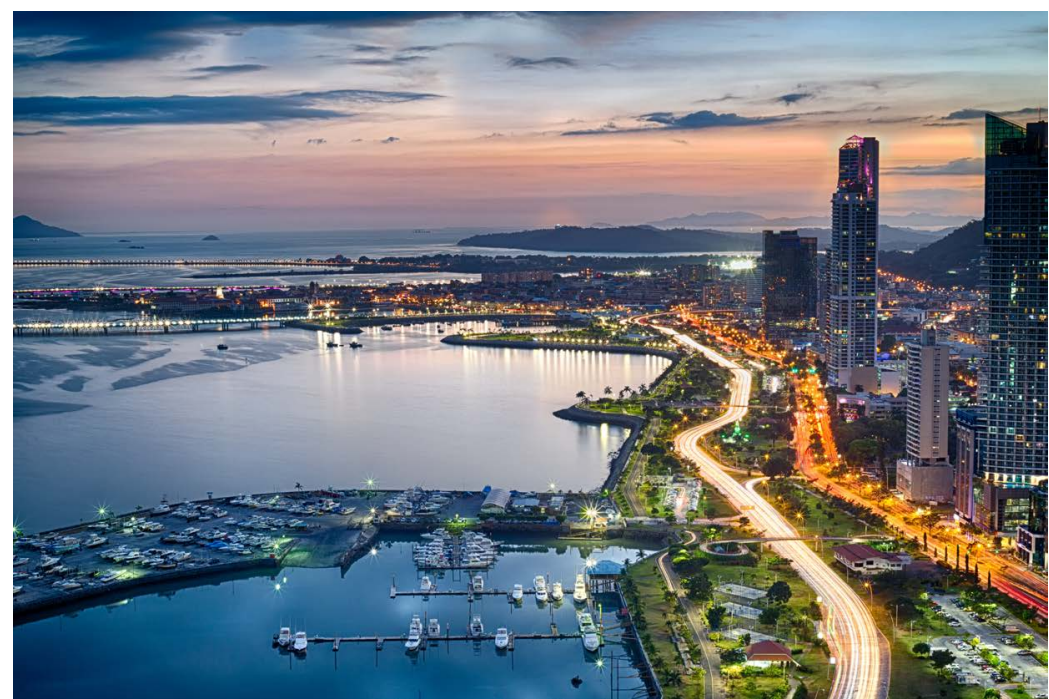

Figure 17. Panama City shoreline along the Pacific Ocean at night. 


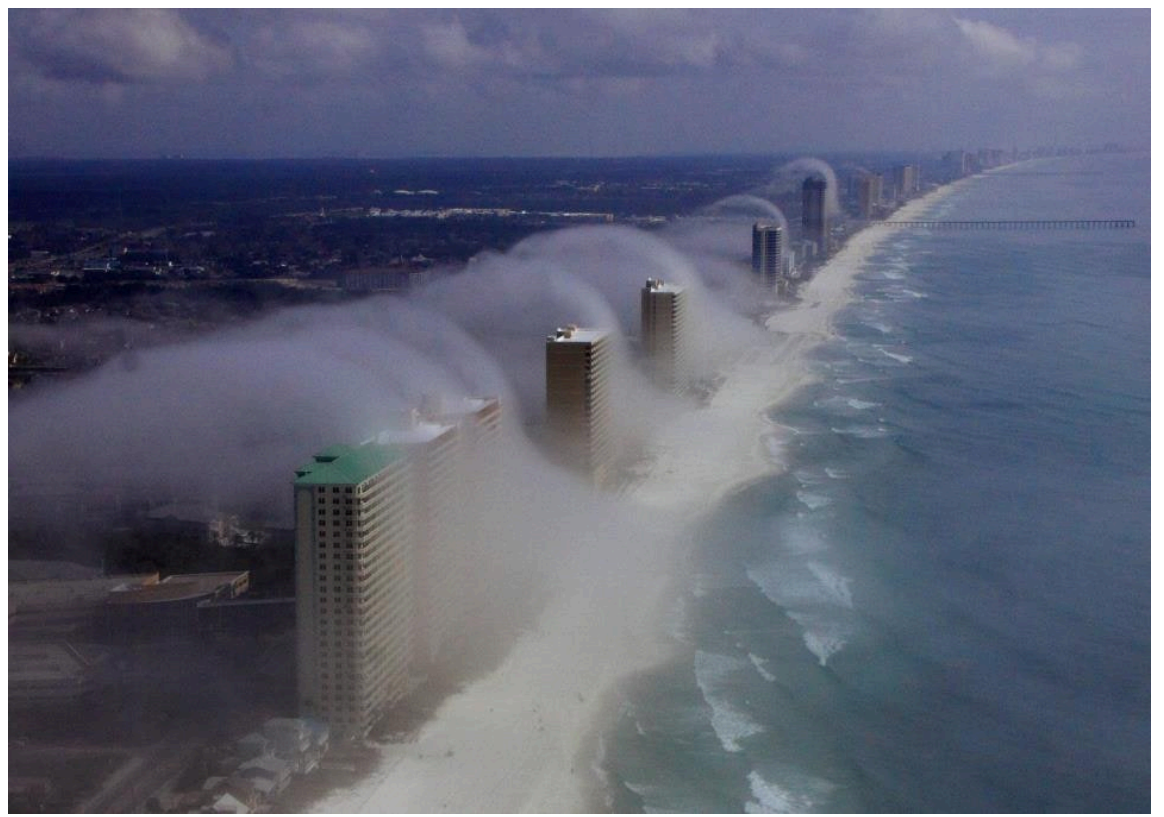

Figure 18. Mist created by temperature difference between the upland and the Pacific Ocean near Panama City.

includes the Cordillera de San Blas Range in the east and the Tabasara Mountain Range in the west [3]. These ranges are separated in the center of Panama by a saddle of lower elevation land. The country's highest peak is Baru, an inactive volcano which has an elevation of $3475 \mathrm{~m}$. The Pacific coast has numerous headlands and bays in the Gulf of Panama. The large Chiriqui Lagoon is where Columbus made his last attempt to find a passage to the East Indies. The continental shelf is much more extensive on the Atlantic side. Most of the 1600 islands are on the Pacific coast side.

Panama has many rivers including the Sixaola, Indio, Changuinola, La Miel, Cricamola and Chagres and all drain into the Atlantic Ocean. The Chepo, Chucunaque, Tuira, Chirigqi, Viejo and Santa Maria rivers drain into the Pacific Ocean [3]. Only $30 \mathrm{~km}$ of the Chepo River and $60 \mathrm{~km}$ of the Tuira River are navigable during the rainy season. Water in the Panama Canal is released from the central highlands rain-fed Lake Gatun (Figure 19) and (Figure 20) and Alyuela lakes.

The soils are clay rich and either brownish or reddish in color [4]. Soil productivity varies with many crops requiring fertilizer to be grown successfully. Shifting subsistence agriculture, called roza, is practiced on the less fertile soils. Under "shifting cultivation", small plots are cleared and cropped for a few years and then abandoned to naturally restore the soil's natural fertility. Alluvial soils formed in stream deposited sediments are in the lower parts of river valleys. Soils along coastal mangrove swamps are productive [4] while the soils developed from volcanic ash are exceptionally fertile. Unfortunately, artificial Lake Gatun, when constructed, covered many of the most productive alluvial soils in Panama. 


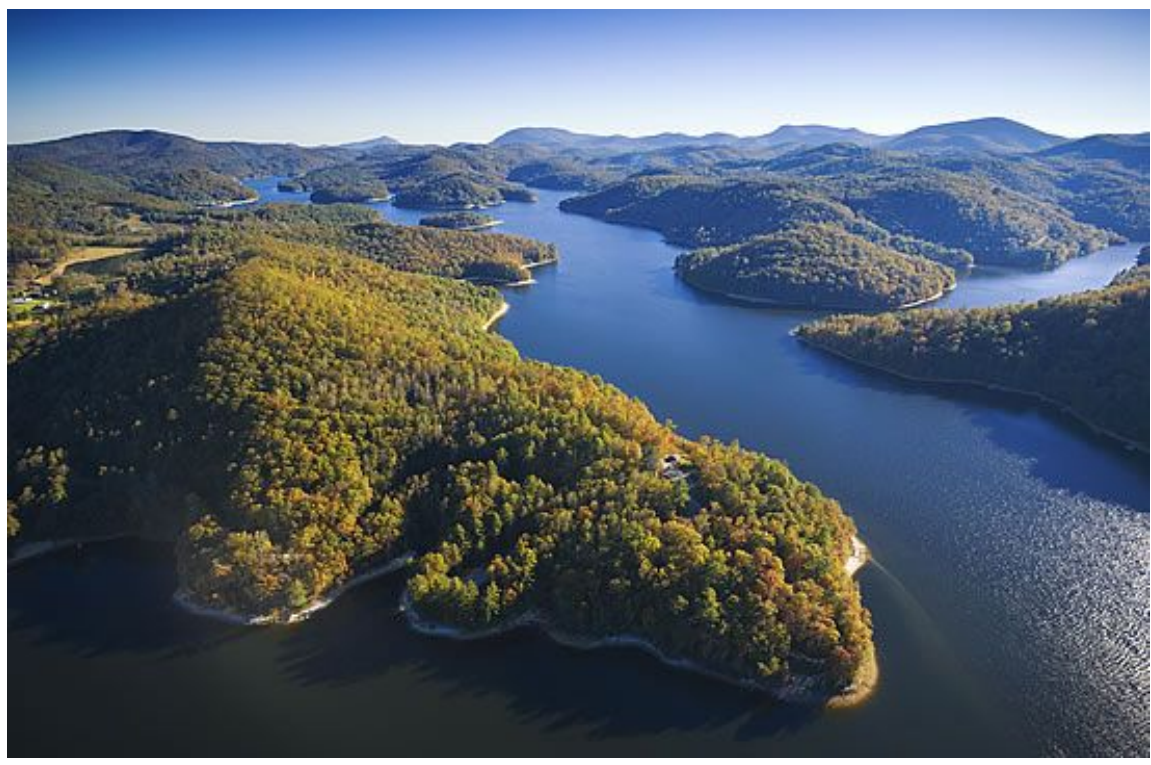

Figure 19. Forested islands and peninsula uplands in Lake Gatun.

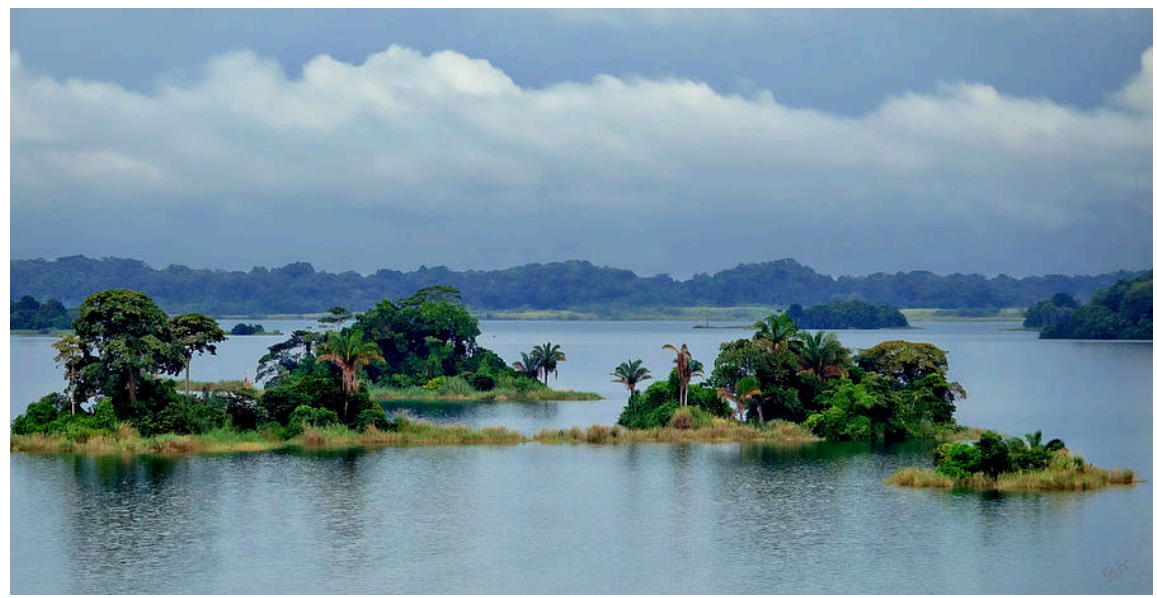

Figure 20. Islands in Lake Gatun which were created in 1913 as a result of the Gatun dam.

The climatic conditions on the Pacific side of Panama differ from the Atlantic region. On the Atlantic side, the Tabasara Mountains face the rain-bearing trade winds and receive twice the average rainfall as the Pacific side. The Caribbean coast receives 150 to $350 \mathrm{~cm}$ per year and the Pacific coast receives 110 to 230 $\mathrm{cm}$. It rains throughout the year on the Caribbean side while the Pacific region has a rainy season from May to December and a dry season from January to April. As a result of rainfall distribution patterns, the Caribbean slopes have a tropical rainforest and savannas (tropical grasslands) are common between the Caribbean shoreline line and the Tabasara Mountains. The mean temperature of the coldest months seldom drops below 26 degrees $\mathrm{C}$ on either coast due to $\mathrm{Pa}$ nama's tropical location. The Panama mountains create three climate zones [3]. A low, hot zone area has elevations below $700 \mathrm{~m}$ which includes $90 \%$ of the country; a temperate zone with elevations between 700 and $1500 \mathrm{~m}$; and a tiny 
cold zone above $1500 \mathrm{~m}$. Coffee is grown in the temperate zone and bananas and cacao are produced in the hot lowlands.

As a result, the Isthmus of Panama has a variety of habitats and landscapes, including savannas, tropical rain forest, tidal lands covered by mangrove trees, cool montane forests, beaches and coral reefs. The land bridge permitted plant and animal species to migrate between continents. Panama's wildlife includes jaguars (Panthera onca), tapirs (Tapirus, terrestris), anteaters (Vermilingua sp.) crocodile (Crocodylus acutus) (Figure 21) and armadillos (Dasypodidae sp.) and a large number of bird species, giant sea turtles, 200 different kinds of snakes and gamen, and 9 different types of monkeys, sloths, and coatimundis. National parks and reserves occupy about $1 / 6^{\text {th }}$ of the land area. The Darien region of eastern Panama is the site of natural parklands. La Amistad National Park, was created in 1988 alongside Costa Rica border [3]. Other national parks in Panama include Portobelo (1976), Chagres (1984) and Coiba (1991).

When the Spaniards came in the $16^{\text {th }}$ century the land was occupied by Kuna, Choco, and Guaymi Native American groups. The population soon included mestizos, a mix of people with Indian and Spanish ancestry. With the construction of the Colon-Panama City railroad, new ethnic groups from all over the world arrived to work on the railroad as laborers. The Native Indians often lived in rainforests. Most of the Indians, including the Choco, engaged in subsistence agriculture, hunting and fishing, while the Kuna were sailors, traders and mechanics and the Guaymi worked on banana plantations in western Panama. Today the Mestizos, who are intermarried with people of West India and African ancestry are the largest Native American group in Panama. They predominately live west of the canal in the savannas and in the central provinces of Colon and Panama.

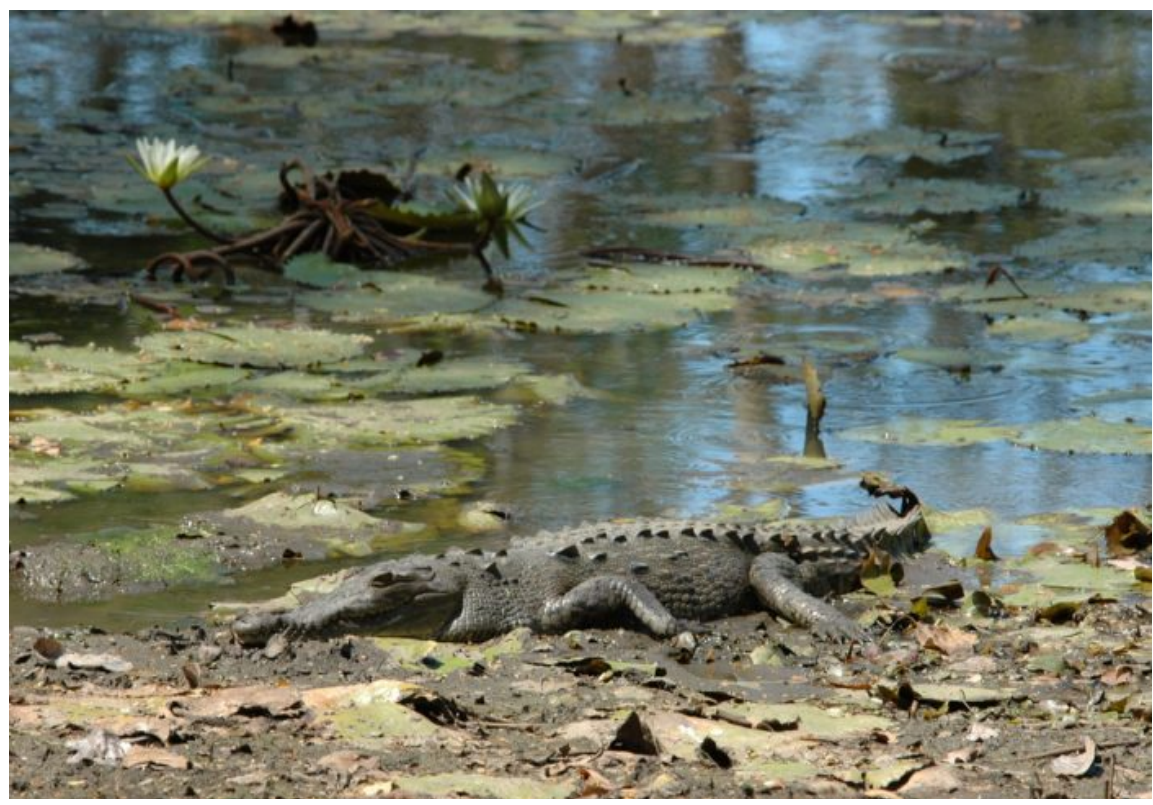

Figure 21. American crocodile in Lake Gatun. 
The construction of the Panama Canal had a great influence on the culture and economy of Panama City. Minorities from all over the world flocked to Panama for work and passed through the canal because it was the shortest route to the gold fields of California and Alaska. Areas of Panama have quicksand where railroad cars have been known to disappear, making construction activity difficult. The Commissary would stock opium for the Chinese workers, which eventually became a problem. Apparently the opium helped them with the unpleasant work and surroundings. When the company commissary stopped stocking opium many workers committed suicide.

Spanish is the official language of Panama. More than $90 \%$ of the population speak Spanish and 10\% speak American Indian languages. Roman Catholicism is the religion of $75 \%$ of the Panamanians, but the number of Protestants grew rapidly in the late $20^{\text {th }}$ century. Today the most densely settled part of Panama is Panama City [1]. The population in 1911 was 336,000 and by the 1990 s had increased to $2,688,000$. Panamanians live predominantly in urban areas with only $30 \%$ living in isolated dwellings and hamlets with many engaged in subsistence agriculture.

\subsection{Economy}

The service sector generates $75 \%$ of Panama's gross domestic product (GDP). Services are related to canal traffic (Figure 22), public administration, mineral extraction (Figure 23) offshore banking and other services. Fishing and agriculture accounted for less than $10 \%$ of the GDP prior to 1990s [1]. Prior to the 1990s, U.S. military forces stationed in Panama supported 5\% of GDP. After U.S. troop withdrawal, the Panamanian government lost millions of dollars. The Panamanian government has re-developed (Figure 24) the previously U.S. controlled properties in the Panama Canal Zone and prime real estate in Panama City. The government repaired the road and rail system and has promoted ecotourism. China, Latin America, Middle East and the U.S. have all invested in

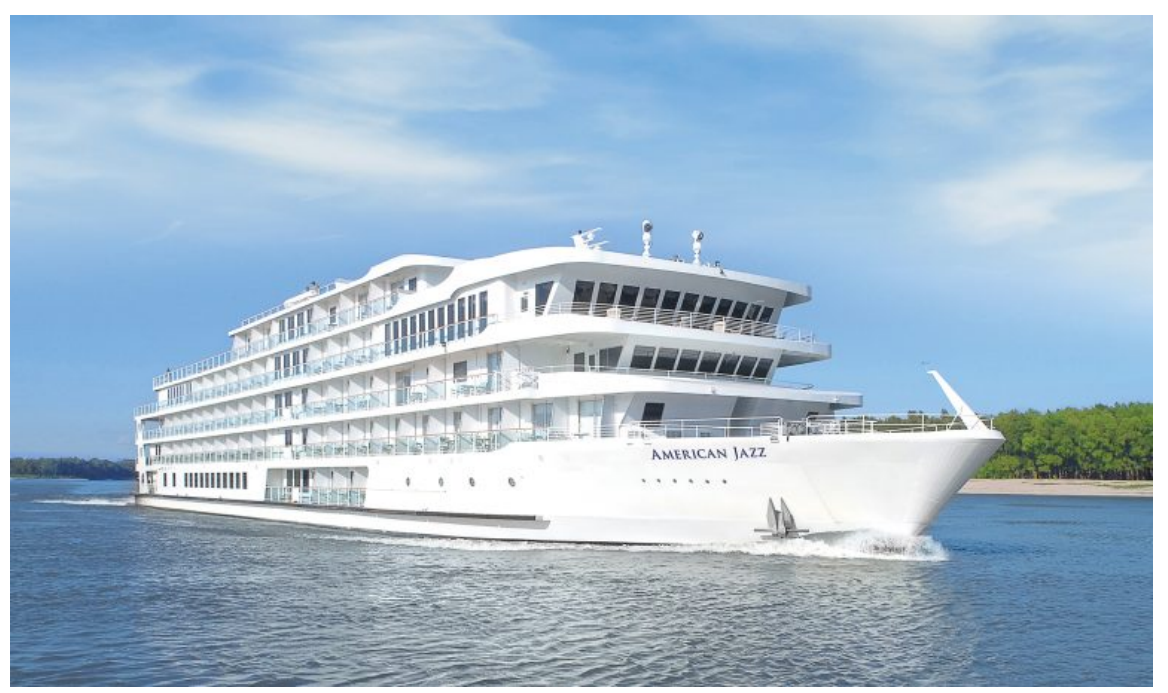

Figure 22. Cruise ship going through the Panama Canal. 


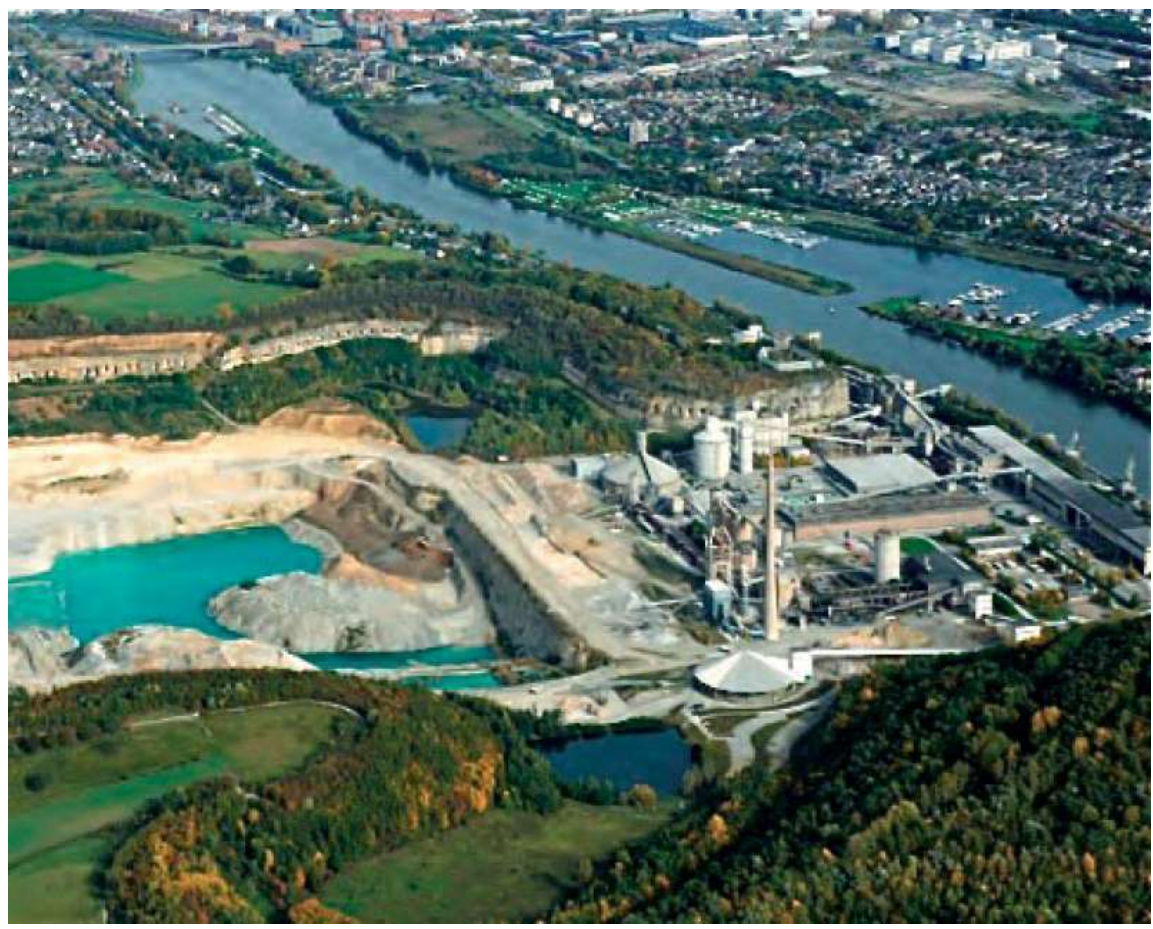

Figure 23. Quarrying and mineral mining along the Panama Canal.

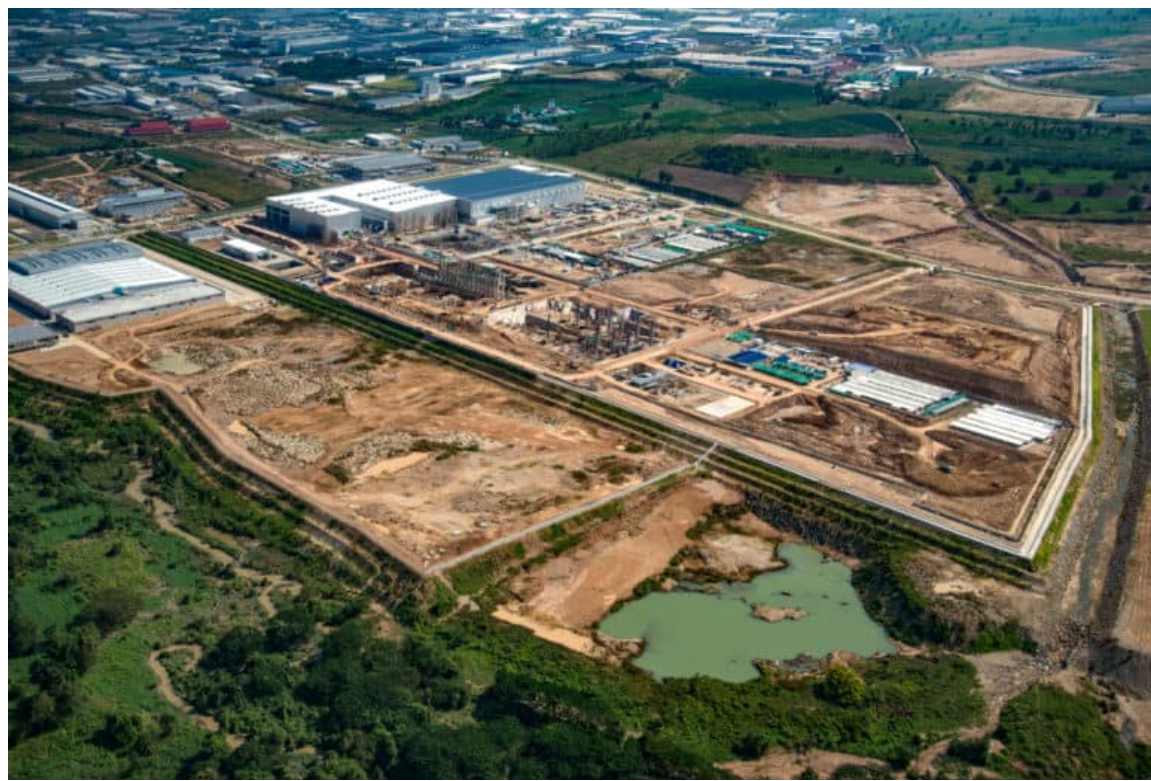

Figure 24. Re-development of former military lands along the Panama Canal.

Panama which has boosted economic growth. Starting in 2020 COVID-19 has disrupted re-development of former U.S military bases and increased the rural and urban crime rate in Panama.

\subsection{Agriculture, Forestry, and Fishing}

Land tenure was enacted in 1962. Now modern commercial agricultural enterprise are adjacent to subsistence and seminomadic agriculture. Common agri- 
cultural products are sugarcane, rice, bananas, plantains, oranges and corn. Livestock includes pigs, cattle and poultry. There is little use of Panama's valuable and abundant forest resources. Few native trees are used for industrial purposes. Mahogany, cativo, tropical cedar and other woods supply sawmills with some log exports. Some large rainforest tracts have been burned, felled and replaced by cattle pastures. Shrimp and lobster are among Panama's most important exports and fishing has become a commercial venture. Fish (anchovy and herring) are caught in shallow waters of the continental shelf in the Gulf of Panama. Aquaculture is being successfully developed. Lobsters are caught off San Blas and Bocas de Toro on the Atlantic side.

\subsection{Resources and Power}

Salt, limestone and clay are the leading mineral products (Figure 23). On a small scale gold, manganese and ferrous sand are also being mined. There are significant deposits of copper, phosphates, bauxite, and coal that have been minimally exploited [3]. Construction material resources include stones and gravel. Petroleum reserves are found on continental shelves in both the Pacific Ocean and the Caribbean Sea.

Electricity was distributed by state-run Institute of Hydraulic Resources, but was privatized in 1998. Much of the electricity comes from hydroelectric dams. The first electric generating plant was opened at La Yeguada in 1975, on the Chepo River in 1976, and at La Fortuna in 1984. Modern Panama industrial development began after WWII. The leading industries are food processing (sugar, fish, cacaco and bananas), production of natural gas and electricity and oil refining. Other products include clothing, shoes, leather goods, alcoholic beverages, paper, chemical, tobacco and cement products [3].

\section{Pesticide and Herbicide Use in the Panama Canal Zone}

During the canal construction phase, the workers were at great risk of dying from malaria and yellow fever. In an attempt to reduce the spread of these diseases, window screens were used on structures and the swamps and wetlands were drained to control the mosquito populations. The Panama Canal was completed and opened in 1913 [3]. The canal channel went through the newly created Lake Gatun, which was periodically covered with hyacinths [5] [6] [7] and other floating plants. An early attempt to eliminate the floating plants was to purchase commercially available white arsenic and mix it with soda bicarbonate (soda) and water [8]. This mixture was then sprayed on floating plants including hyacinths. The arsenic desiccated and killed the water plants and the residues laced with arsenic sank to the bottom of Lake Gatun and the Panama Canal. Thus the water soluble arsenite and arsenate were disbursed throughout the lake and canal waters and sediments. After 1932 the white arsenic (As has no half-life) and soda usage was discontinued and replaced by other herbicides including 2,4-D. The U.S. military bases constructed throughout the Panama Can- 
al Zone also had challenges in controlling the tropical fauna and flora. The solution used was commercially available herbicides and insecticides which were obtained through the Federal Catalog to control weeds and insects.

The U.S. Army technical manual [9] and the U.S. Army Medical Department Center and School subcourse [10] for groundskeepers were used to provide guidance on how to eradicate specific weeds, such as kudzu, and insects on the military base grounds (Figures 25-30). The military properties, housing units, and connecting roads were sprayed daily using truck-mounted sprayers apparently filled with DDT. In the 1940s and 1950s termite stake studies [7], with

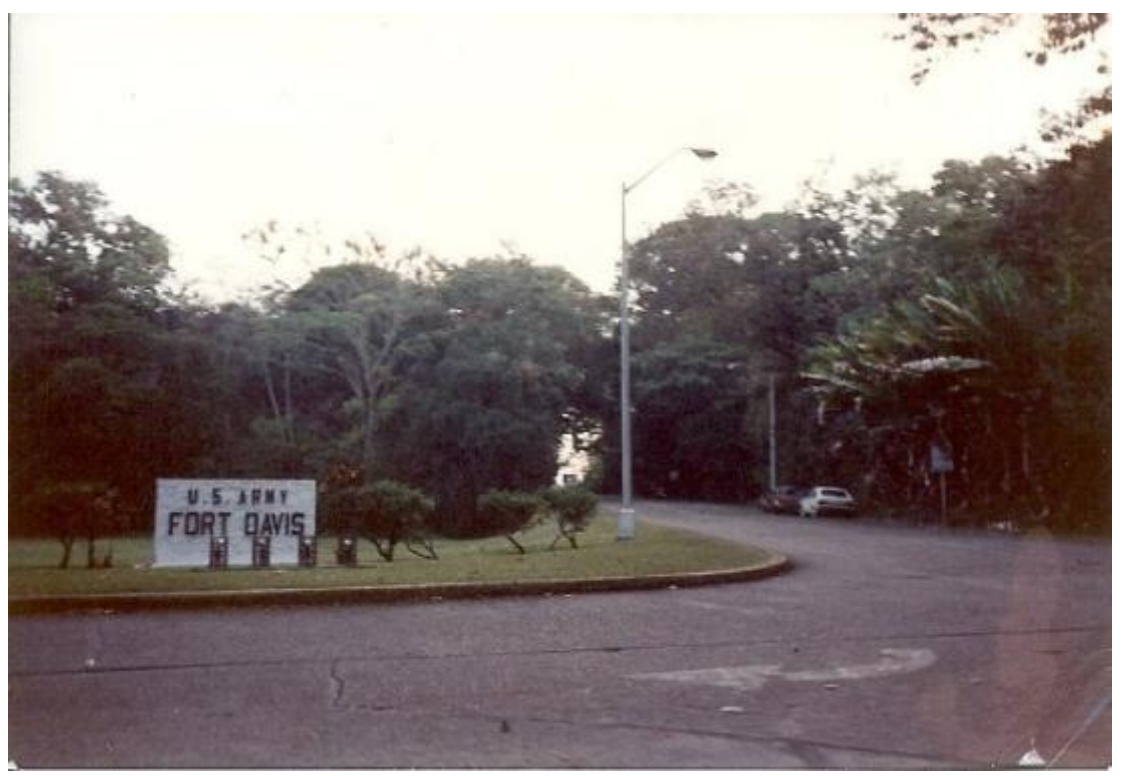

Figure 25. U.S. Army Fort Davis sign. The base was located on the Atlantic side of the Panama Canal Zone.

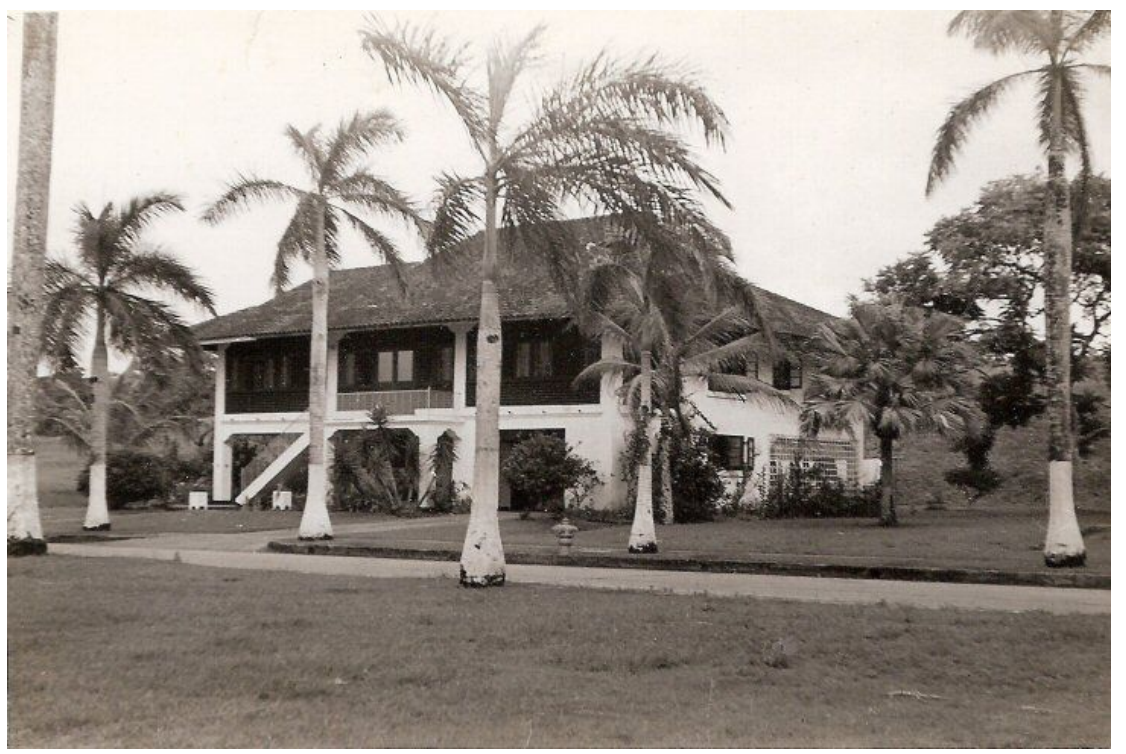

Figure 26. Housing at Fort Davis near Colon, Panama. The residences and fort were sprayed nightly to control the insects. DDT was the most commonly used pesticide. 


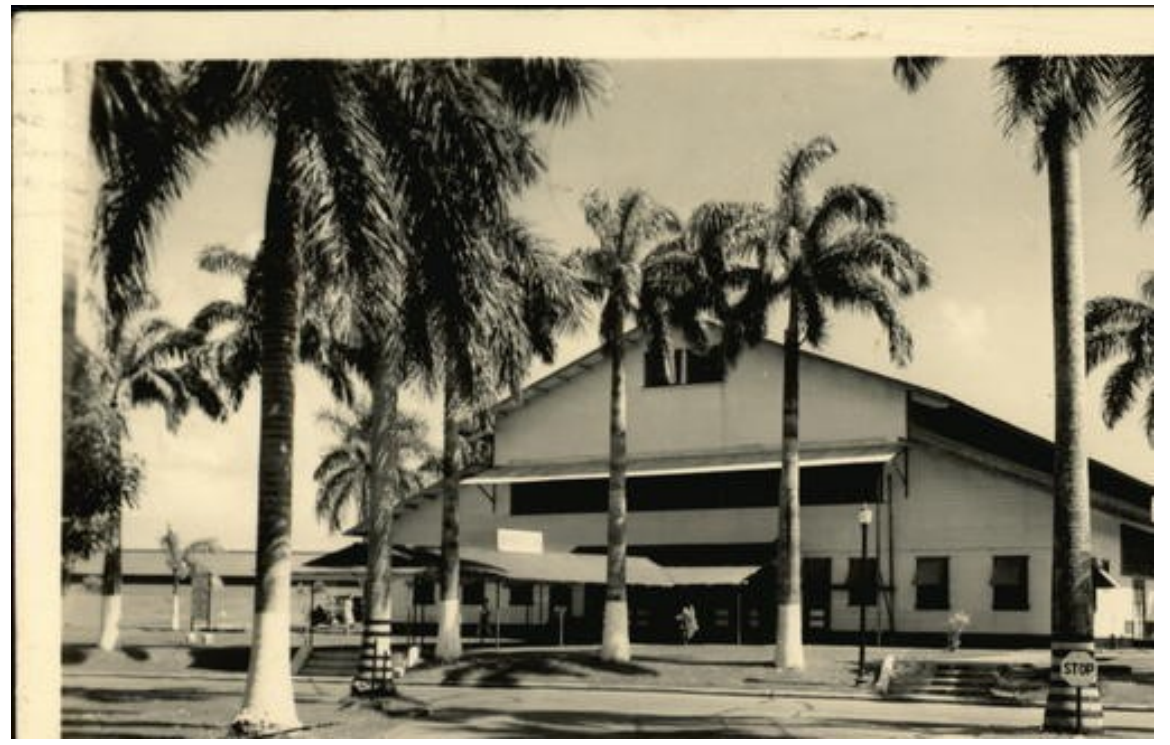

Figure 27. Service center at Fort Davis near Colon, Panama.

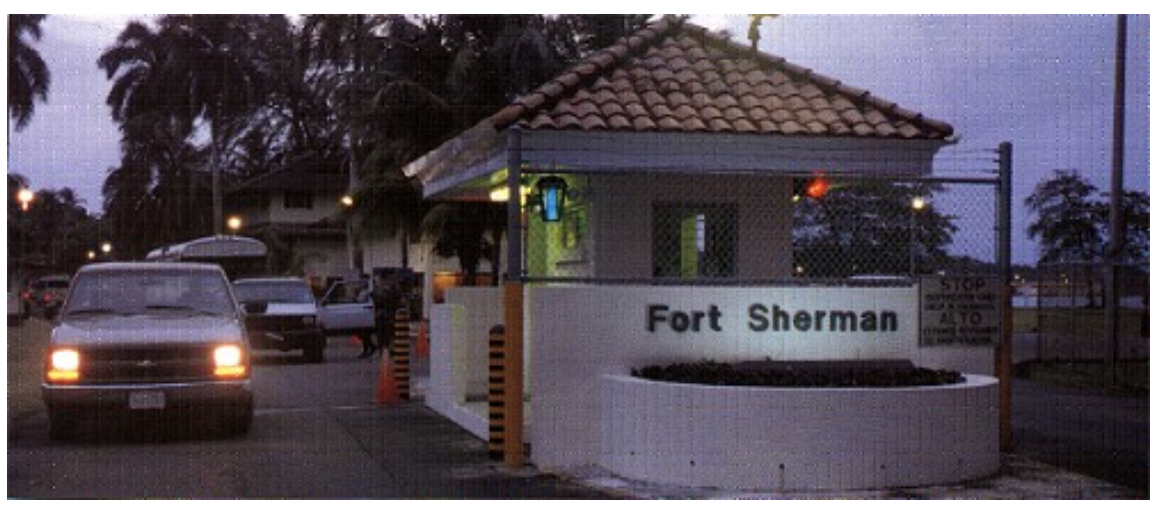

Figure 28. Fort Sherman sign and location of the United States military's Jungle School for many decades.

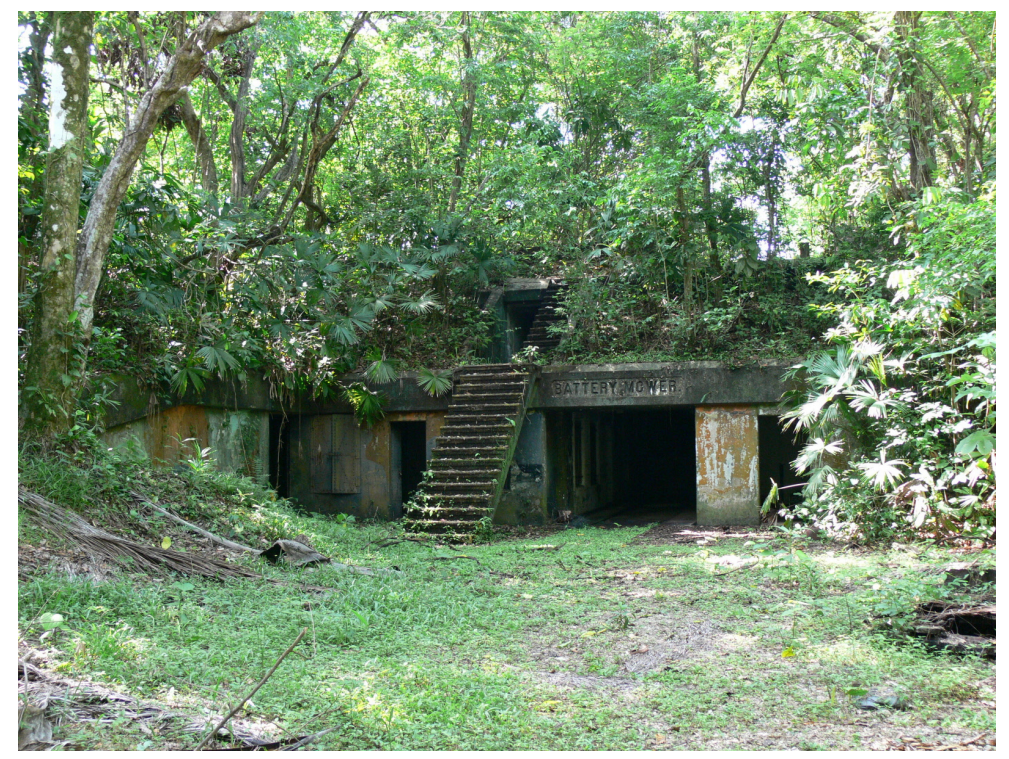

Figure 29. A former battery at Fort Sherman. The jungle is reclaiming the site. 


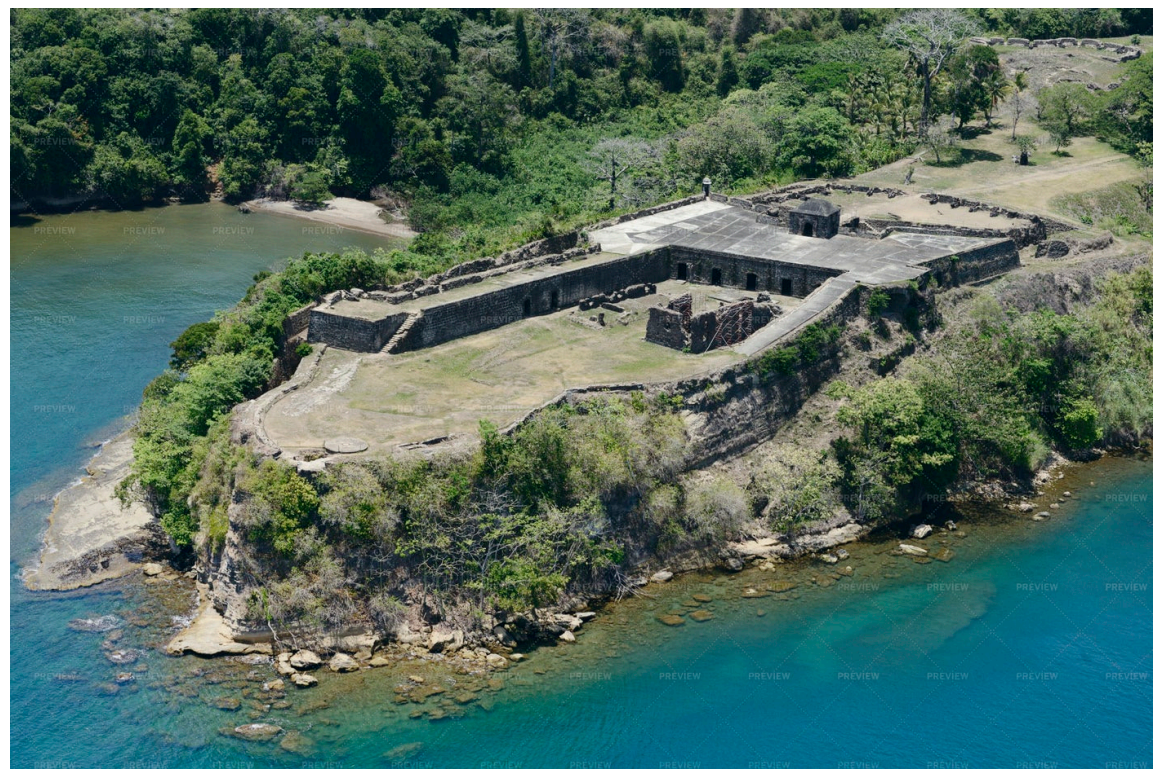

Figure 30. Peninsula with a former military structure on Fort Sherman.

stakes dipped in pesticides and other chemicals including lead arsenate, sodium arsenite and DDT were conducted by the USDA, Forest Service on Barro Colorado Island where the Smithsonian headquarter buildings are located [7]. In 1963 the Curundu Jungle Test site at Fort Clayton on the Pacific side was used to determine which pesticide and chemically treated stakes would not be eaten by the termites. The commercially available herbicide, 2,4-D was used in Lake Gatun since 1948, which was the feeder lake water source for the Panama Canal.

\subsection{Yellow Fever}

The Istmus of Panama was an ideal environment for mosquitoes [11] [12]. Yellow fever was the most feared of the scourges afflicting humans in Panama. Many workers thought the "miasmas" or heavy, bad-smelling vapors that rose out of the wetlands and swamps were the cause of diseases. The "miasma theory" of disease causality persisted from the $13^{\text {th }}$ century through the $19^{\text {th }}$ century, even with the discovery that mosquitoes (Aedes aegypti) carried the disease which hindered the Gorgas sanitation plan in 1904. The initial symptoms of yellow fever were a headache, fever and back pain, followed by prostration, bleeding and decreased urine production. Finally, delirium and black vomit brought death (Figure 31) within a few days. During the July 10, 1904 to November 22, 1905 time period, there were 246 cases. Most patients were treated at the Anoco Hospital (Figure 32) in Anoco, Panama [8].

\subsection{Malaria}

The successful construction of the Panama Canal required the control of malaria. Sir Robert Ross, a British Doctor, discovered in 1907 that malaria was transmitted by mosquitoes. In Cuba, regulations were put into effect in 1899 by 


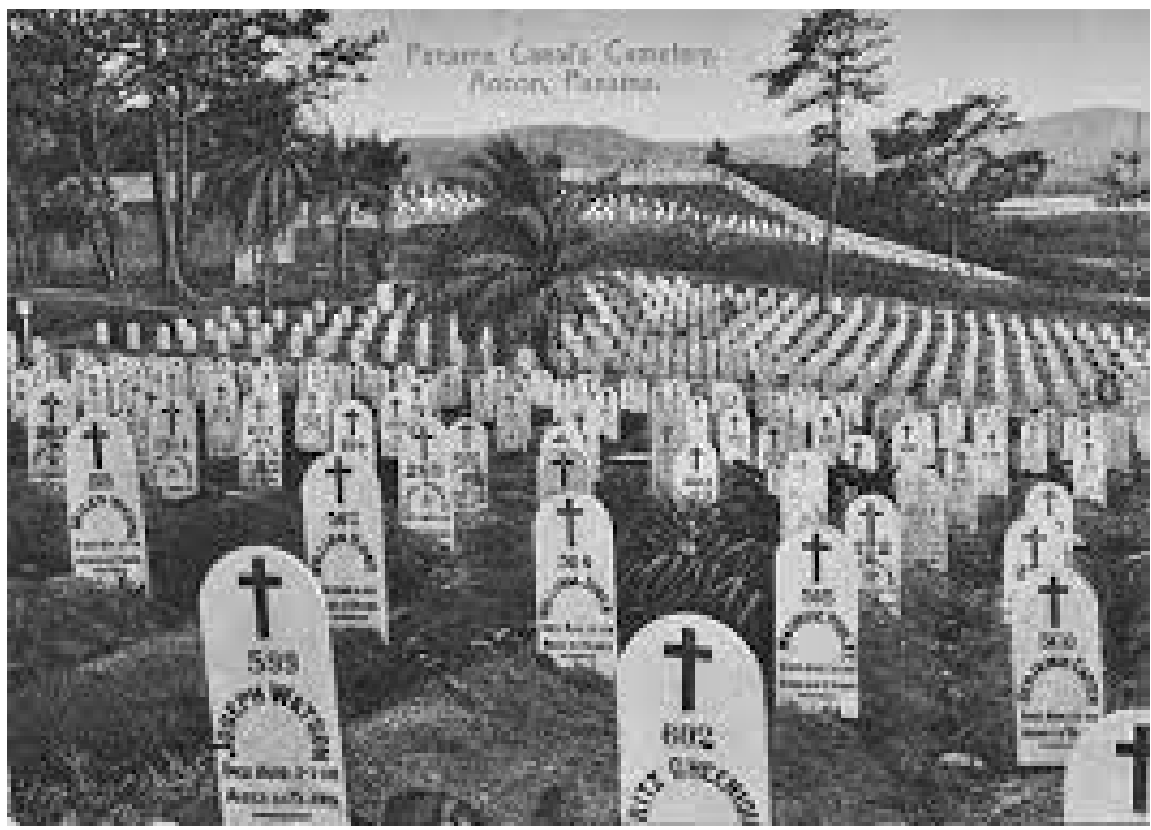

Figure 31. A cemetery used to bury the dead who died of malaria and yellow fever during the 1910 s.

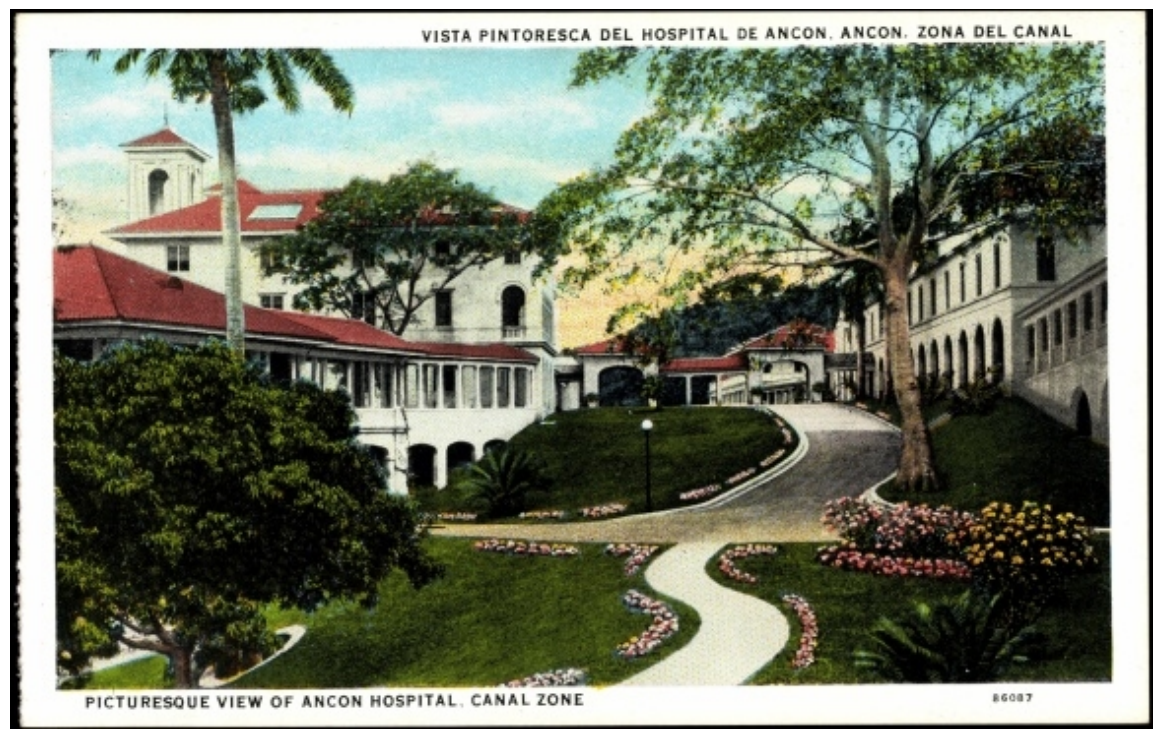

Figure 32. The Ancon hospital located in the Panama Canal Zone where the malaria and yellow fever.

the U.S. Army Medical Officer to control of yellow fever which consisted of extensive drainage to reduce breeding of mosquitoes and putting screens on houses. The Isthmus of Panama was an ideal environment for mosquitoes [11] [12]. The same concept was applied a few years later in Panama [8]. In June 30, 1904 the Sanitary Department was created and headed by Colonel Gorgas. He applied a military style campaign to eradicate mosquitoes, which, while costly, greatly reduced the breeding of mosquitoes and yellow fever and malaria transmission [8]. 


\subsection{White Arsenic}

The white arsenic (As) used between 1913 and 1932 to kill the floating plants in both Lake Gatun and the Panama Canal is an extremely toxic soluble white solid made by burning arsenic $\left(\mathrm{As}_{2} \mathrm{O}_{3}\right)$. Arsenious oxides, commonly known as white arsenic, are obtained as a by-product from the smelting of lead, copper, and certain other metals by roasting of sulfide ores and arsenopyrite. Sweden was the United States primary source of white arsenic in the 1960s. The inorganic forms, including arsenate/arsenite (found in soil, water and food) and arsenic trioxide, are human health concerns [3].

\subsection{Barro Colorado Stake Termite Stake Study}

The USDA, Forest Service [7] conducted chemical and pesticide dip stake studies in 1943, 1946 and 1952 on Barro Colorado Island for termite control. These chemicals included lead arsenate, sodium arsenite, DDT and chlordane. Arsenate and arsenite are water soluble and can either move in surface runoff water or leach into the groundwater. In 1963 the Curundu Jungle Test Site at Fort Clayton on Pacific side was used in additional stake tests.

\subsection{Malathion}

Malathion which acts as acetyl cholinesterase inhibitor is an organophosphate insecticide that affects the nervous system and increases the risk of Parkinson's disease [11]. Malathion was registered for use as an insecticide in the United States beginning in 1956. Malathion ground applications were usually made by truck mounted fogging equipment which was true in Panama Canal Zone.

During the American Vietnam War (1965 to 1973), a large number of troops came down with malaria [13]. To kill mosquitoes that carried malaria in South Vietnam, DOD converted aircraft that were previously used to spray Agent Orange and other tactical herbicides to spraying malathion, an insecticide as part of Operation Flyswatter. However, starting in 1970 C-123 aircraft, previously used to spray Agent Orange and other tactical herbicides including Agent Blue, were re-located to the United States Air Force Reserved units as well as international airfields. In 1970 three C-123 aircraft that were previously contaminated with TCDD and As during Operation Ranch Hand in South Vietnam [14] before they were sent to Howard Air Force base in Panama [14]. These aircraft were used to spray malathion on the Panama Canal Zone from 1970 to 1973.

\subsection{DDT}

DDT, dichlorodiphenyltrichloroethane, is colorless, tasteless and an almost odorless crystal chemical compound. DDT was one of the first chemicals used as a widespread pesticide. After WWII it was used in agriculture and households until it was banned in the United States in 1972. Austrian chemist Othmar Zeidler first synthesized DDT in 1874. Swiss chemist, Paul H. Muller discovered the 
DDT insecticidal action in 1939. Paul H. Muller was awarded the Nobel Prize in Medicine and Physiology in 1948. DDT was used during the last half of WWII to limit the spread of insect-born malaria and typhus [8]. DDT became available for public sale in October of 1945. Government and industry promoted its use as a household and agricultural pesticide. The 1962 publication of Rachel Carson's book "Silent Spring" [15] focused the opposition on DDT. The book questioned the practice of broadcasting potentially dangerous chemicals into the environment without an investigation of their health and environmental effects. The book's author claimed DDT caused cancer. The U.S. military removed DDT from the supply chain in 1965 due in part to resistance of body lice to DDT and replaced it with lindane [16]. Agricultural use of DDT was banned in the United States in 1972. However, DDT was sprayed extensively in the Panama Canal Zone (not officially part of the United States) after 1972. DDT remained effective in killing mosquitoes and dramatically reduced malarial infections. From the 1950 s to the 1980 s more than 40,000 ton/yr of DDT were used in worldwide agriculture and mosquito control. During this time period, the World Health Organization (WHO) was the largest purchaser of DDT in the World. DDT was manufactured by 15 different chemical companies, including Monsanto, Ciba, and Montrose Chemical. Worldwide use was banned in 2004.

\subsection{2,4-Dichlorophenoxyacetic Acid}

2,4-Dichlorophenoxyacetic acid (2,4-D) is an organic compound [17] with the chemical formula $\mathrm{C}_{8} \mathrm{H}_{6} \mathrm{Cl}_{2} \mathrm{O}_{3}(2,4-\mathrm{D})$. This systemic herbicide has growth regulator effects that selectively kill plants by causing uncontrolled growth in most broadleaf weeds. The herbicide has been commercially available since 1945 . The herbicide 2,4-D is one of the most widely used and oldest defoliants in the world. After the patent expired it was produced by many chemical companies. There are over 1500 herbicide products which contain 2,4-D as the active ingredient. It is widely used as a commercial lawn herbicide and as a weed killer on cereal crops and orchards.

The 2,4-D discovery occurred during World War II (late 1930s) independently by four groups in the United Kingdom and the United States under wartime secrecy. The initial publication of 2,4-D's ability to control broadleaf weeds as a selective herbicide came in 1944 . The herbicide 2,4-D was one of the ingredients in Agent Purple and was used in the Malayan Emergency. 2,4-D was also contained in other tactical herbicides: Agent Orange, Agent White, Agent Green, and Agent Pink which were used during the Vietnam War [13]. Agents Purple, Pink, Green and Orange also contained 2,4,5-T contaminated with TCDD $(2,3,7,8$-Tetrachlorodibenzodioxin) which caused adverse human health effects. 2,4-D kills both terrestrial and aquatic broadleaf weeds [17]. It was and is still used to control aquatic weeds in the Panama Canal and Lake Gatun which interfered with boating and shipping. In other waterways it was used to unclog irrigation canals and hydroelectric equipment. Some ester forms of 2,4-D are 
highly toxic to fish, moderate toxicity to birds and mammals, and slightly toxic to aquatic invertebrates [15]. Men, often Panamanians, who worked with 2,4-D are at risk for abnormally shaped sperm and have fertility problems.

Under most environmental conditions 2,4-D esters and amine salts are not persistent [15]. The herbicide 2,4-D is broken down by microbes in soil in a process involving hydroxylation. A number of 2,4-D degrading bacteria have been isolated and characterized from a variety of environmental habitats. Breakdown is $\mathrm{pH}$ dependent, but is highly mobile and leaches as a result of low affinity in mineral soils and sediment.

In an aerobic mineral soil the degradation of 2,4-D is rapid (half-life of 6.2 days) [18]; however it has a 15-day half-life in anaerobic mineral soils. In anaerobic aquatic environment, 2,4-D was moderately persistent to persistent (half-life of 41 to 333 days) [18]. The herbicide 2,4-D has been detected in streams and shallow groundwater but at low concentrations in United States rural and urban areas. No data are available for the Panama Canal Zone.

\subsection{The Herbicide 2,4-5-Trichlorophenoxyacetic Acid}

A chlorophenoxyacetic acid herbicide 2,4,5-Trichlorophenoxyacetic acid (2,4,5-T) is a synthetic auxin created to defoliate broad-leafed plants. It was developed in the late 1940s and was slowly phased out in United States in the late 1970s due to toxicity concerns and not manufactured after 1985 [19]. The herbicide 2,4,5-T itself is toxic. An intake rated of $10 \mathrm{mg} / \mathrm{kg} /$ day 2,4,5-T can cause adverse alterations in organisms. In addition, the manufacturing process for $2,4,5-\mathrm{T}$ can contaminate this herbicide with unknown amounts of 2,3,7,8-tetrachlorodibenzo- $p$-dioxin (TCDD).

The half-life of 2,4,5-T is similar to 2,4-D. The degradation of 2,4-D and 2,4,5-T are rapid (half-life of 6.2 days) in an aerobic mineral soil [18] but have a 15-day half-life in anaerobic mineral soils [18]. The herbicides are moderately persistent to persistent (half-life of 41 to 333 days) in anaerobic aquatic environments.

\subsection{The By-Product $2,3,7,8$-Tetrachlorodibenzo- $p$-Dioxin}

The by-product $2,3,7,8$-tetrachlorodibenzo- $p$-dioxin (TCDD) is an unanticipated contaminant created during the manufacture of the herbicide 2,4,5-T. TCDD has a very long half-life and does not degrade easily. Each batch of commercially available 2,4,5-T herbicide has an average concentration of about 2 to 3 ppm of TCDD but can vary between $0.05 \mathrm{ppm}$ to $50 \mathrm{ppm}$ [19]. TCDD is an endocrine disrupter and can cause a variety of chloracne, cancers and developmental and reproductive effects.

TCDD is not water soluble and can adhere to leaf surfaces, organic material, fine soil particles and sediments which can be carried downstream by runoff water flow into wetlands, ponds and lakes such as Lake Gatun. Dioxin TCDD can bio-accumulate in aquatic species and become bio-magnified throughout the food chain via mollusks, fowl and fish eaten by humans and other animals [20].

The Lake Gatun and Panama Canal sediment should be checked for concen- 
trations of TCDD which is probably bound to organic materials and soil particles within the lake, wetlands, waterways and ponds. TCDD could be diluted in Lake Gatun depending on the distance from shore. TCDD can be eliminated from the surface of Lake Gatun waters by photo degradation. The half-life of TCDD in the clear waters of Lake Gatun is based on high intensity of ultraviolet radiation hitting the lake waters. The largest fraction of TCDD in most waters binds to detritus, algae, organic materials and mineral matter. These TCDD particles do not remain in the water column but attach to and are deposited with the sediment. By measuring particle concentration in water and their rate of settling the rate of loss can be calculated. Very little TCDD is dissolved in water due to its hydrophobic nature. TCDD in the sediment particles can be returned to the water when sediment is re-suspended [21].

Sediment re-suspension occurs in Panamanian lake waters which are shallow and easily churned by wave and wind action [22]. TCDD is ultimately eliminated from the aquatic system via microbial degradation within sediments or when TCDD particles found in sediments are buried deeply in waterways or lakes [22]. Degradation by anaerobic microorganisms in sediments or permanently saturated soils can occur over time periods of 10, 20, 50 years to centuries [18].

TCDD in the food chain affects both Panamanian capacity to derive livelihoods from fish and other aquatic plants and animals and their own health. The half-life of dioxin varies depending on site conditions. In surface soil the half-life is between 1 and 3 years when fully exposed to sunlight. In an aerobic soil the half-life is between 11 and 15 years and estimated to be 20 to 50 years or more when buried in the tropical anaerobic soil. In waterways and lake sediments the half-life can be more than 100 years [18].

\subsection{Tactical and Commercial Herbicides}

About 39.4 million liters of Agent Orange were sprayed during the course of the Vietnam War. Agent Orange had a short half-life and rapidly degraded, remaining toxic for only a short period, days or a few weeks at most. The tropical vegetation quickly regrew requiring repeated applications. Unfortunately, Agent Orange and the defoliants with 2,4,5-T in their formulations had an unanticipated contaminant or by-product 2,3,7,8-Tetrachlorodibenzodioxin (TCDD), which had a very long half-life under anaerobic conditions and did not easily degrade. Many batches of Agents Pink, Purple, and Green had higher concentrations of TCDD than early batches of Agent Orange [19]. However, later batches of Agent Orange TCDD in the late 1960s had much greater TCDD levels as a result of higher manufacturing temperatures [13].

The term "dioxin" represents a class of about 300 chemicals which are formed (usually unintentionally) when chlorine at very high temperatures binds to a molecule that contains carbon (C). This occurs in the bleaching of paper/pulp and chemical manufacturing processes. In the late 1960s, the U.S. military demanded greater quantities of Agent Orange from private chemical companies 
(there was a shortage which resulted in Agent White use, without 2,4,5-T and the by-product TCDD, being used), the manufacturing processes were speeded up by companies such as Dow Chemical and Monsanto (company correspondence included in the 1984 Vietnam Veteran lawsuit discovery documents) by raising the temperature about 5 degrees centigrade which increased the amount of 2,3,7,8-Tetrachlorodibenzodioxin (TCDD) in the herbicide by up to three thousand times. As noted earlier, the average concentration of TCDD in similar commercial herbicide in each batch of 2,3,5-T was about $2-3 \mathrm{ppm}$ but the range ran from $0.05 \mathrm{ppm}$ to almost $50 \mathrm{ppm}$. So, the use of tactical grade Agent Orange manufactured to "military specifications" in the late 1960s had considerably more TCDD in it than the commercially available herbicide and would have greatly increased the TCDD levels in the Panama Canal Zone if it had been offloaded and used.

Apparently, the chemical companies asked the DOD if the higher levels of the contaminant TCDD posed a problem. The DOD leadership team suggested that they needed more Agent Orange for the war effort and favored any manufacturing process which produced more Agent Orange in less time [19]. Since the Agent Orange was going to be sprayed primarily on the Viet Cong, with some collateral damage, it was apparently not seen by the military (in the middle of the American Vietnam War) as a problem. Furthermore, adding to the decision process was a significant shortage of Agent Orange. Consequently, the private chemical companies, who were under orders from the U. S. government and military to produce vast quantities of Agent Orange, complied. If they had not complied during war time they were at risk of being taken over by the U. S. government and military. So, if tactical herbicides with a different formulation and higher levels of TCDD were used instead of commercial herbicides in Panama Canal Zone, the amount of TCDD applied to the landscape could have been increased by as much as 3000 times and would have contributed to even higher TCDD levels in the Panama Canal Zone soils and water. Soil and sediment sampling of the military base grounds, Panama Canal and Lake Gatun should be considered to demonstrate that only commercial herbicides with low TCDD levels (less than $50 \mathrm{ppm}$ ) were used in the Panama Canal Zone. Commercial spraying should have only resulted in trace amounts of TCDD remaining in the soils, sediments and water.

The most toxic of all the dioxins and dioxin-like compounds is TCDD [23]. The U.S. National Academy of Sciences estimated the Vietnam War defoliation project released an estimated between 110 and 180 kilograms of TCDD into South Vietnam environment [19] [23]. The US National Toxicology Program (NTP) and the International Agency for the Research on Cancer both listed dioxin TCDD as known human carcinogens. Dioxins are endocrine disrupters and can cause certain chloracne, cancers and developmental and reproductive effects. Although TCDD is not water soluble and can adhere to leaf surfaces, organic materials, fine soil particles, and sediments that can be carried by runoff into 
downstream waters and deposited in wetlands, ponds, and lakes [24] [25]. In this way, TCDD can bio-accumulate in aquatic species and can become biomagnified throughout the food chain via mollusks, fowl and fish eaten by humans and other animals [20] [24].

\subsection{Transport and Fate of Agent Orange and Commercial Herbicides 2,4-D and 2,4,5-T Containing Contaminant Dioxin TCDD}

A recently released report of the United States Government Accountability Office (GAO) focused on the actions needed to improve the accuracy and communication of information regarding storage and testing locations of Agent Orange outside of Vietnam [14] including Kelly Air Force Base in Texas [26]. This GAO report confirmed that the Military Sea Transportation Service directly chartered merchant vessels to carry tactical herbicides through the Panama Canal during the Vietnam War. These tactical herbicides, including Agents White, Blue and Orange, were stored vertically on pallets in internal storage compartments on the vessels. There is no official evidence to show the tactical herbicides were ever offloaded in Panama [27].

However, there are other documents which support the presence of similar commercial herbicides 2,4-D and 2,4,5-T containing with unknown amount of dioxin TCDD. A December 1976 Environmental Sampling Report for the Panama Canal Zone showed chlorophenoxy herbicides were detected in the soil samples from the Canal Zone [14]. Chlorophenoxy herbicides are identified by the Centers for Disease Control and Prevention as 2,4,5-T based herbicide containing TCDD [14]. In the $14^{\text {th }}$ Annual Meeting of U.S. Army Corps of Engineering report on the "Aquatic Plant Control Research Program" there is a section which notes the June 1978 initiation of large-scale testing of 2,4-D on water hyacinth [4] [5]. Since commercially available 2,4-D was used on military bases in Panama Canal Zone this herbicide would have been available for testing on the hyacinth in Lake Gatun and could have been used as a test site.

\subsection{U.S. Federal Government and Military Use of Commercial Herbicides with 2,4,5-T with Dioxin TCDD Contaminant in Panama Canal Zone}

The U.S. government and military have for more than 60 years maintained those tactical herbicides such as Agent Orange and Agent Blue were never "off loaded in the Panama Canal Zone nor aerially sprayed on the Tropical Forests of the Panama Canal Zone" [28]. This statement has over the years been challenged by many Panama Vietnam Era Veterans who claimed that they handled and/or were exposed to toxic chemical sprays [14]. Panama veterans who were exposed to commercial herbicides including 2,4,5-T containing unknown amount of dioxin TCDD, have filed for VA benefits but have been repeatedly denied benefits [12] since the tactical herbicides were not officially offloaded and/or applied to the Panama Canal Zone landscape [27]. However, commercial herbicides con- 
taining 2,4,5-T and an unknown amount of dioxin TCDD were used on the U.S. military base grounds [9] [10]. These herbicides were very similar (composition and strength) but often lower in TCDD than the restricted use tactical herbicides being transported through the Panama Canal Zone to the South China Sea for use during the Vietnam War. The U.S. government and military declared, on the official record [27], that tactical herbicides were never used in the Panama Canal Zone. However, DOD was not really claiming that "unrestricted commercial herbicides" were never requisitioned, offloaded, handled and applied by military personnel to the military base grounds and perimeter fences [9] [10] [12] at the direction of the Base Civil Engineer Commanders.

It is also assumed that any aerial spraying done by aircraft only involved commercially available herbicides including 2,4-D and 2,4,5-T containing dioxin TCDD and arsenic [11]. However, three C-123 aircraft that were used to spray malathion in the Panama Canal Zone may have been previously contaminated with tactical herbicides in other theaters of operation including South Vietnam. After President Nixon stopped Agent Orange spraying in 1970, three C-123 aircraft previously used to spray tactical herbicides in Vietnam [28] and contaminated with tactical herbicides (including Agent Orange, Agent White and Agent Blue) residues in their spray tanks, were relocated via a transport ship in 1970 to Howard Air Force base in Panama. These TCDD and As contaminated C-123 planes were used from 1970 to 1973 to spray malathion in the Panama Canal Zone [28]. This may have resulted in trace amounts of tactical herbicide Agent Orange (TCDD) and Agent Blue (As) [29] being added to the soils and water of the Panama Canal Zone.

A GAO review of DOD and VA documents [30] identified multiple examples of incomplete and inaccurate information on the DOD's list of tactical herbicide test and storage sites such as Kelly Air Force Base in Texas. GAO obtained command histories and original DOD reports which provided operational details about the procurement, distribution, use, and disposition of Agent Orange [20] and its components, 2,4-D and 2,4,5-T containing unknown amount of dioxin TCDD. GAO concluded that there was extensive documentation on the herbicide management program at Kelly Air Force Base for the American Vietnam War time period and more specifically years 1966-1973. According to an Air Force Logistics Command's Office of History monograph, the command directly responsible for managing Agent Orange was the Directorate of Aerospace Fuels at the San Antonio Air Material Area located at Kelly Air Force base [14]. During the Vietnam War Kelly Air Force Base was also a subcomponent of the U.S. Air Force Logistics Command.

GAO documentation shows that quantities of the two components of the tactical herbicide Agent Orange were stored at Kelly Air Force Base in Texas in 1972. There were 38,940 gallons of 2,4,5-T containing TCDD and 106,260 gallons of 2,4-D stored on the base [14]. The uneven quantities of these two herbicides suggest that not all the tactical herbicides in storage were in the pre-mixed to form of Agent Orange, Herbicide Orange or Butyl Ester. Perhaps Agent 
White a tactical herbicide used when Agent Orange was in short supply, which contains only 2,4-D but not 2,4,5-T with TCDD was also in Kelly Air Force base storage [14]. After the American Vietnam War ended in 1973 the tactical herbicide Agent Orange with 2,4-D and 2,4,5-T containing an unknown amount of dioxin TCDD herbicide components in the stock pile was apparently transferred to the United States Department of Agriculture (USDA) for brush control which could have been one of the sources of the herbicides used by the USDA, Forest Service in the Western United States in the 1970s to control the brush and broadleaf weeds after clear cutting. This was the subject of a 2021 PBS documentary Independent Lens on "People vs. Agent Orange" [31] and a Vietnam Veteran News podcast 2086 by Mack Payne [32]. In order for the tactical herbicides stored at Kelly Air Force base to be transferred to the USDA for agency use in the Western United States it appears that the tactical herbicides would have had to be reclassified from formulated "Military Specifications" [33] to formulated "Federal Specifications" before being approved for use and applied by the USDA, Forest Service, timber company and chemical company partners in the Western United States to prevent shrub and broadleaf weed regrowth competition with trees on clear cut public forest lands.

\subsection{Fate of Tactical Herbicides Stored at Kelly Air Force Base at the End of the American Vietnam War?}

GAO records also show that approximately 173,910 gallons of the tactical herbicide Agent Blue [14] containing cacodylic acid (As) was also stored at Kelly Air Force base. It is not clear how this massive amount of arsenic-rich Agent Blue was disposed of after the American Vietnam War officially ended in January of 1973. It could have been transferred to USDA, including the Forest Service, for brush control along with the Herbicide Orange (Agent Orange) components 2,4-D and 2,4,5-T containing TCDD. If DOD transferred the tactical herbicide Agent Blue to USDA, the transfer of a herbicide, originally formulated to "Military Specifications" [33] to a federal agency with only the ability to use herbicides formulated to "Federal Specifications", for another federal agency use to control brush and would have required Federal Insecticide, Fungicide, and Rodenticide Act (FIFRA) approval. If Agent Blue was applied by the USDA, Forest Service in the 1970s, arsenic, which does not have a half-life, would have remained in the Western United States soils. However, it is not clear if the tactical herbicide, Agent Blue, was ever transferred by the DOD, with proper FIFRA approval, from Kelly Air Force base chemical stockpile to USDA along with other tactical herbicides including Agent Orange with 2,4-D and 2.4.5-T containing an unknown amount of TCDD for brush control which could have been one of the sources of the herbicides used by USDA, Forest Service in the Western United States [31] in the 1970s.

If Agent Blue was not used on Federal lands in Western United States, then what happened to the 173,910 gallons of Agent Blue that were stored at Kelly Air Force base after the tactical herbicide was no longer needed in South Vietnam? 
Was Agent Blue destroyed in Kelly Air Force base burn pits? If so the smoke coming from the burn pits would have become an environmental problem since the particulate and ash would have contained toxic As contaminants and aerosols. The military base personnel could have been exposed to and inhaled arsenic laden smoke. Was it buried in the soil at Kelly Air Force base? If so, the water soluble As would eventually leak from the barrels in the last 50 years and into the groundwater. If so, the military base personnel could have been exposed to arsenic and some Kelly Air Force Base Vietnam Era Veterans [12] have already filed VA claims for benefits as a result of exposure to either TCDD or arsenic. The fourth option would have been to transport the Agent Blue to Davis-Monthan Air Force Base in Tucson, Arizona for weed control around the aircraft and perimeter fence (Figure 33 and Figure 34). This would have been in

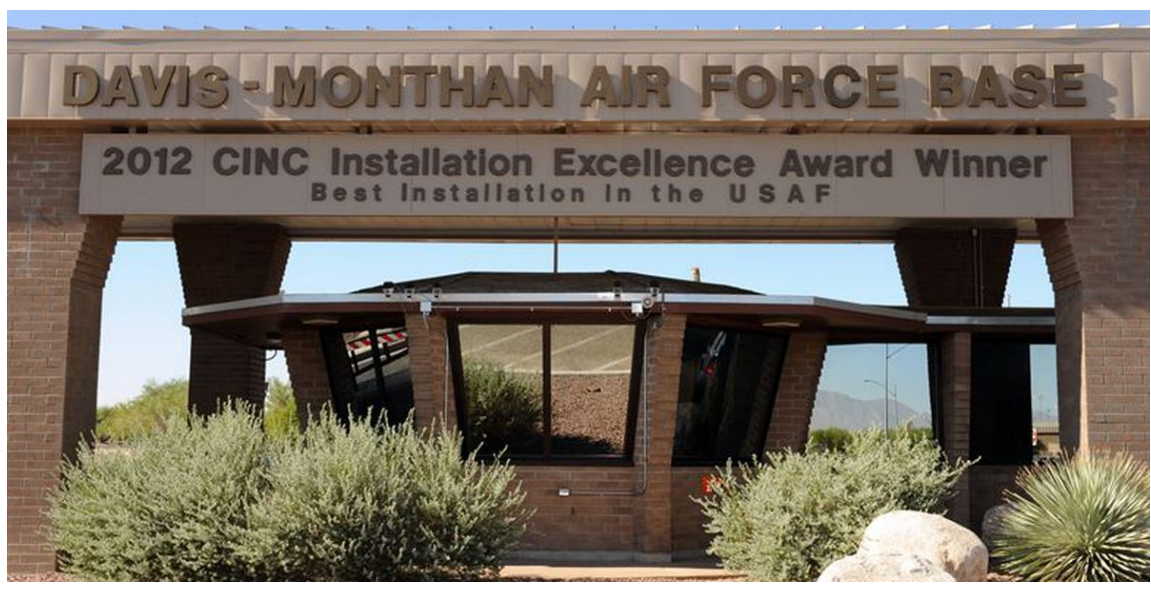

Figure 33. Davis-Monthan Air Force Base Headquarters in Arizona. The final resting place for U.S. military planes.

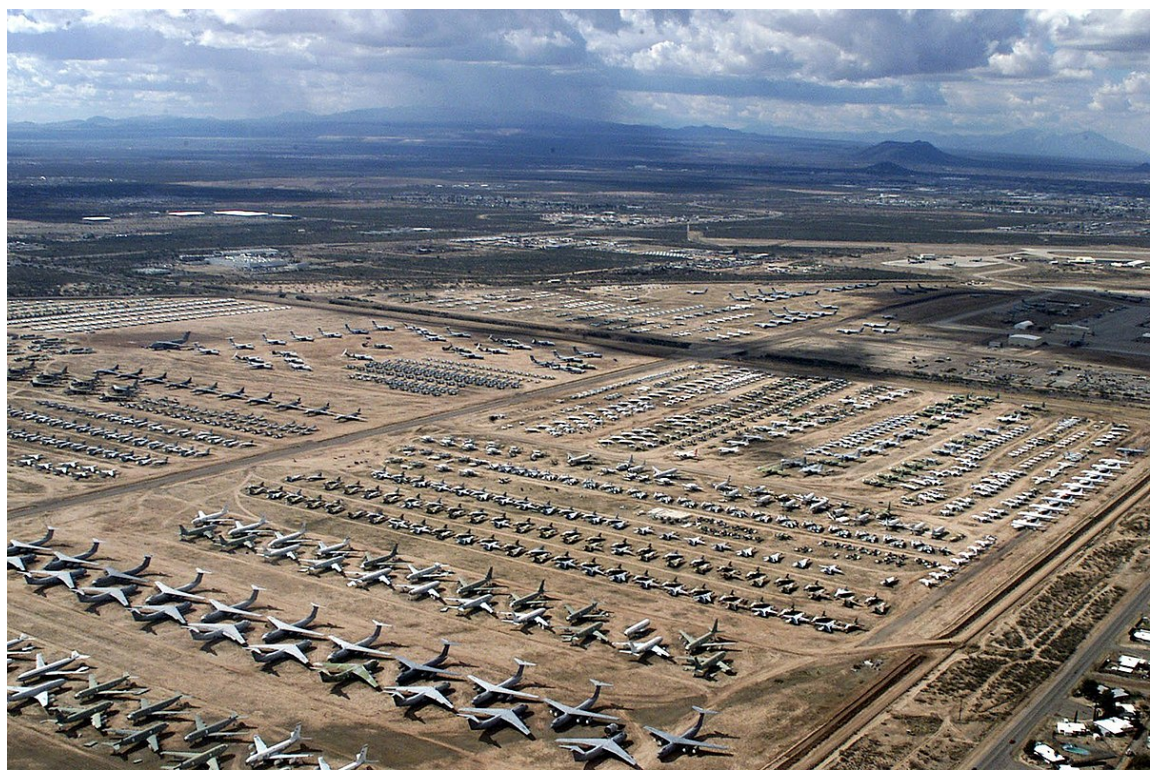

Figure 34. Perimeter fence at Davis-Monthan Air Force base in Arizona where the U.S. military planes go to die. 
addition to the Agent Blue barrels shipped from South Vietnam directly and from Johnston Island indirectly [30] between 1972 and 1977. So how did the DOD use up or destroy all of the arsenic based Agent Blue left over from the American Vietnam War, including the storage stockpile at Kelly Air Force base in Texas, after President Nixon stopped the spraying of all tactical herbicides in 1971 ?

\subsection{Fate of Commercially Available Herbicides on Military Bases in Panama Canal Zone}

The herbicides 2,4-D and 2,4,5-T containing low levels of TCDD were commercially available and thus could be ordered and used separately by any Federal Agency, including the military and shipped to and used on the Panama Canal Zone military base grounds. While there are no documents which prove tactical herbicides, such as pre-mixed Agent Orange, were ever offloaded in Panama Canal Zone [33] and/or sprayed on the tropical forests and islands in the Panama Canal Zone, however, there are commercial ship transport records, which show commercial herbicides, Orange, Ester-Butyl, 2,4-D and 2,4,5-T containing the contaminant TCDD were used on military bases in the Panama Canal Zone [33]. Even if tactical herbicides were never off loaded and sprayed in the Panama Canal Zone the commercial herbicides including 2,4,5-T by-product containing unknown levels of TCDD were used on the military base grounds and perimeter fences by military base personal to control the vegetation and insect pests and would have added TCDD to the Panama Canal Zone environment. There is evidence that DDT and malathion (first registered in 1956) [17], 2,4-D and 2,4,5-T with the contaminant dioxin TCDD were sprayed on Panama Canal Zone highways, structures, military grounds and perimeter fences using sprayers mounted on trucks in the Panama Canal Zone.

\section{Conclusions}

The Panama Canal linked the Pacific and Atlantic coast ecosystems and destroyed a natural barrier, the Isthmus of Panama, by connecting of the two oceans, creating Lake Gatun on the Chagres River, covering up fertile agricultural lands and swamps. During the Panama Canal construction phase, many workers died from tropical diseases including malaria and yellow fever. To reduce the mosquito population, malathion was sprayed at the canal construction site since the 1960s. Malathion has a relatively short half-life and does not appear to degrade into other environmentally harmful by-products. After the damming of the Chagres River to create the Lake Gatun for the Panama Canal, floating plants, including hyacinth started to clog the flow of the water through Lake Gatun. A mixture of white arsenic, soda and water was sprayed from 1913 to 1930s from boats on the floating vegetation. The arsenic, which has no half-life and is water soluble, was deposited in Lake Gatun waters and sediments.

When the three contaminated C-123 aircrafts were shipped from South Vietnam to Howard Air Force Base in 1970, with the tactical herbicides residues 
were still in the spray tanks, containing high levels of TCDD and As. These contaminated C-123 aircraft and spray tanks were then used to aerially spray malathion on the Panama Canal Zone landscape in an attempt to reduce the number of malaria cases. The tactical herbicide residues in the spray tanks would have mixed with malathion and then sprayed on the Panama Canal Zone soils and water. It is true that only trace amounts of As and dioxin TCDD would have ended up on the Panama Canal Zone from the spraying of malathion. Since TCDD has a long-half life under anaerobic conditions in soil and water and As has no half-life the trace amounts of these toxins would still be present in the Panama Canal Zone soils and water.

The C-123 flight crews, maintenance specialists, and mechanics would have been exposed to the tactical herbicide residues containing TCDD and As. Some of these U.S. Air Force, Panamanian Vietnam Era veterans have already filed VA benefit claims as a result of using and serving these contaminated aircraft [12] [29]. The VA Office of Compensation has continued to support the DOD position that "no tactical herbicides were ever offloaded or sprayed in the Panama Canal Zone". However VA was willing to make a one-time exception for the flight crews and the maintenance mechanics assigned to these three contaminated C-123 stationed at Howard Air Force Base from 1970 to 1973. These aircraft were used to spray malathion on the Panama Canal Zone and each affected Air Force Veterans VA benefits case were re-considered separately. On August 13, 2021 H.R. 5026-117 ${ }^{\text {th }}$ Congress (2021-2022) was introduced to amend title 38, United States Code, to provide for a presumption of service, connection for illnesses associated with service in Armed Forces in the Panama Canal Zone.

For Panama Canal security reasons, 14 military bases or areas were established in the Panama Canal Zone [21]. These bases were in the tropics and the jungle fauna and flora needed to be controlled to make life bearable for the military personnel. The 1967 U.S. Army grounds manual [9] and the 2010 U.S. Medical Department and Center and School sub course [10] gave very specific instructions to the grounds crews on how to deal with each type of weed. For example, kudzu was to be killed by spraying a commercially available herbicide, 2,4,5-T. During the post-Vietnam War years the expanded use of this herbicide containing unknown amounts of TCDD increased dioxin TCDD levels in the environment. Pesticides and chemicals flowed into Lake Gatun via surface runoff either in solution or attached to the sediment. These pesticides including 2,4,5-T containing TCDD, can be bio-accumulated in fish and birds and feed and enter into the human food supply [13]. The extent of the current chemical and pesticide contamination on former Panama Canal Zone U.S. military base grounds and in Lake Gatun and the Panama Canal channel is unknown. Systematic soil sampling of former military bases, chemical disposal sites, and sediment sampling of the Lake Gatun or the Panama Canal sediments is needed to determine if mitigation is still required. 


\section{Acknowledgements}

The research study and publication were published with support and approval of the Merry Band of Retirees committee which include nine U.S. Army and Vietnam Era veteran members and four Agricultural College Professors. The co-authors acknowledge the support and many contributions of the Veterans of Panama Canal Zone and the Military Veterans Advocacy of Slidell, Louisiana. A special thanks to Mike Tharp, a former Vietnam War correspondent who won a Bronze Star, for editing the article. The co-authors appreciate the Vietnam Center and Sam Johnson Archive willingness to archive this article and make it available to future Vietnam War historians.

\section{Conflicts of Interest}

The authors declare no conflicts of interest regarding the publication of this paper.

\section{References}

[1] Encyclopedia Britannica (2020) Panama Canal Zone, Chicago, Illinois.

[2] Johnson, S.P. (1963) American Legacy in Panama: A Brief History of Department of Defense Installations and Properties. United States Army South.

[3] Wikipedia: The Free Encyclopedia (2020) Panama. Wikimedia Foundation, St. Petersburg.

[4] Bennett, H.H. (1929) Soil Reconnaissance of Panama Canal Zone and Contiguous Territory. Technical Bulletin No. 94 Soil Investigations, Bureau of Chemistry and Soils. USDA, Washington DC.

[5] Sanders, D.R., Theriot, R.F. and Theriot, E.A. (1982) Organism Impacting Water Hyacinth in the Panama Canal. Miscellaneous Paper A-82-1, U.S. Army Engineer Waterways Experiment Station, CE, Vicksburg.

[6] Hearne, J.S. (1966) The Panama Canal's Aquatic Weed Problem. Hyacinth Control Journal, 5, 1-5.

[7] Beal, R.H. (1981) Termite Control Studies in Panama. Research Note SO-280. USDA, Southern Forest Experiment Station, Forest Service, New Orleans.

[8] Panama Canal Review (1963) The Panama Canal. The Panama Canal Company. A History of the Panama Canal French and American Construction Efforts. Balboa Heights, Panama.

[9] Department of Army (1967) Repairs and Utilities Ground Maintenance and Land Management. Technical Manual Tm5-630. Headquarters, Department of Army.

[10] U.S. Army Medical Department Center and School (2010) Pesticides in the Military. Subcourse MD0173. Edition 100. Fort Sam Houston, Texas.

[11] Mack, G. (1944). The Land Divided-A History of the Panama Canal and Other Isthmian Canal Projects.

[12] Tornoe, D. (2017) The Travels of Orange and Other Toxins in the Panama Canal Zone. Amazon.

[13] Olson, K.R. and Morton, L.W. (2019) Long-Term Fate of Agent Orange and Dioxin TCDD Contaminated Soils and Sediments in Vietnam Hotspots. Open Journal of Soil Science, 9, 1-34. https://doi.org/10.4236/ojss.2019.91001 
[14] Chisholm Kilpatrick Blog (2019) Agent Orange Locations: Panama and Kelly Air Force Base.

https://cck-law.com/blog/agent-orange-locations-panama-and-kelly-air-force-base/

[15] Carson, R. (2002) Silent Spring. Mariner Books. Houghton Mifflin Harcourt, Boston.

[16] National Pesticide Information Center (2020) NPIC 2,4-D Technical Fact Sheet.

[17] USEPA 2,4-D Reregistration Eligibility Decision (2005) Associated RED Fact Sheet. Archived 2008-05-17 at EPA.

[18] Senkknen, S. and Passivirta, J. (2000) Degradation Half-Life Times of PCDDs, PCDFs and PCBs for Environmental Fate Modeling. Chemosphere, 40, 943-949. https://doi.org/10.1016/S0045-6535(99)00337-9

[19] Sills, P. (2014) Toxic War: The Story of Agent Orange. Vanderbilt University Press, Nashville.

[20] Stoye, E. (2016) Toxic Legacy of Agent Orange Lives on in Vietnam. Chemistry World.

[21] Sommerfreund, J.K., Ganhi, N., Diamond, M.L., Gerino, M., Bellucci, L.G. and Guiliani, S. (2010) Contaminant Fate and Transport in the Venice Lagoon: Results from a Multi-Segment Multimedia Model. Ecoloxicology and Environmental Safety, 73, 222-230. https://doi.org/10.1016/j.ecoenv.2009.11.005

[22] Horodoir, R., Nguyen, K.D. and Polcher, J. (2006) Smulating Tropical River Phumes, a Set of Parametrizations Based on Macroscale Data. A Test Case in the Mekong Delta Region. Journal of Geophysical Research-Oceans, 111, C09036. https://doi.org/10.1029/2005JC003392

[23] Hsieh, D.P.H., Chiao, F.F., Currie, R.C. and McKone, T.E. (1994) Intermedia Transfer Factors for Contaminants Found at Hazardous Waste Sites: 2,3,7,8Tetrachlorodibenzo-p-Dioxin (TCDD). Final Draft Report, Department of Environmental Toxicology, University of California, Davis.

[24] Goscha, C. (2016) Vietnam. A New History. Basic Books, New York.

[25] Olson, K.R. and Tharp, M. (2020) How Did the Passaic River, a Superfund Site near Newark, New Jersey, Become an Agent Orange Dioxin TCDD Hotspot? Journal of Soil Water Conservation, 75, 33A-37A. https://doi.org/10.2489/jswc.75.2.33A

[26] Wikipedia (2020) List of Former United States Military Installations in Panama. Wikimedia Foundation, St. Petersburg.

[27] Young, A.L. (2009) The History, Use Deposition, Disposition and Environmental Fate of Agent Orange. Springer, Berlin.

[28] Veterans Affairs Benefits Administration (2016) Compensation Service Letter Dated September 1, 2016 Addressed to Congressman Earl I. "Buddy Carter".

[29] Olson, K.R. and Cihacek, L. (2020) The Fate of Agent Blue, the Arsenic Based Rice Herbicide, Used in South Vietnam during the Vietnam War. Open Journal of Soil Science, 10, 518-577. https://doi.org/10.4236/ojss.2020.1011027

[30] Martini, E.A. (2012) Agent Orange: History, Science and the Politics of Uncertainty. University of Massachusetts Press, Amherst.

[31] Adelson, A., Taverna, K. and Bernard, V. (2021) The People vs. Agent Orange: Two Women, One American and One Vietnamese Fight to Hold the Chemical Industry Accountable for a Devastating Legacy. Independent Lens, Public Broadcasting Service.

[32] Payne, M. (2021) Episode 2086-Vietnam Veteran News Podcast. PBS. Show Exposes 
Agent Orange Secrets. https://vietnamveterannews.com/episode-2086

[33] Young, A.L. and Wolverton, B.C. (1970) Military Herbicides and Insecticides. Technical Notes AF ATL-TN-70-1. 